\title{
Ecophysiology of Wild Plants and Conservation Perspectives in the State of Qatar
}

\author{
Bassam T. Yasseen and Roda F. Al-Thani \\ Additional information is available at the end of the chapter
}

http://dx.doi.org/10.5772/55305

\section{Introduction}

State of Qatar is a peninsula extended from Arabia desert as outcrop in the western Arabian Gulf, located in an area of the world which is warm and humid; its land is considered as arid or semi-arid and highly saline. The common type of landscape is rocky desert, depressions and salt marshes, and in general it is flat to undulating. Such environment could have great impact on the biodiversity of flora and fauna, since limited number of wild plants and animals has been recorded in this area. The vegetation of Qatar is comprised of herbaceous plants, dwarf shrubs and a few tree species. Woody plants, succulents, and perennial grasses and sedges withstand successfully the severe drought of the summer. Soil in Qatar is generally shallow sandy calcareous, overlying rocky bed rock. The available nutrition for native plants is poor with salty soil; they are adapted and tolerate different physical and chemical factors. These adaptations also affect the type, abundance, and occurrence of microorganisms. However, this country is endowed with natural resources especially gas and oil; their revenues have been used to support all aspects of social life including the expansion of urban and industrial sectors as well as supporting the scientific research and its international obligations. In fact, Qatar has engaged with numerous international activities such as humanitarian aids and hosting international sport competitions and political meetings. The expansion in the industrial activities might put the ecosystem at real risk; some habitats are disappearing, and pollution of the environment could be another possible threat of such activities in the long run. Three challenges facing scientists and the decision makers in the State of Qatar: (1) restoration of the endangered habitats due to the industrial and urban activities, (2) phytoremediation of wastewater and soil which might be affected by gas and oil industry, and (3) establishment of wide scale institutes to deal with the modern techniques of gene technology to develop transgenic crop and native plants to cope with harsh and polluted environments. Therefore, this chapter of 
the book (Agricultural Chemistry, ISBN 980-953- 307-1002-1) is dedicated to address the efforts of restoration, phytoremediation and modern technologies in the State of Qatar. The following objectives have been suggested to discuss these efforts and to implement scientific solutions of the problems facing the environment in this region: (1) describe the environment and the plant wild life in the Gulf region in general and in particular in the State of Qatar, (2) understand the ecophysiology and mechanisms of adaptation of plants and microorganisms under drought and saline environments, (3) comprehend the impact of human and industrial activities on the natural habitats, and the restoration and phytoremediation efforts to maintain the environment, and (4) foresee the perspectives of genetic manipulation of crop and native plants, and using the possible gene bank of native plants to improve the phytoremediation processes.

\section{The environment in the Gulf region}

By definition of aridity, as a function of rainfall and temperature and the daily follow-up of meteorological data; the Arabian Gulf region is considered as arid or semi-arid. This region is absolutely among the warmest regions of the world; the temperatures in the summer season reach levels as high as 50 degrees Celsius or may be above. The general outlook of the mean rate of precipitation in this region showed clearly that the rain is scarce and not exceeds the rate of $152 \mathrm{~mm}$ per year [1]. Thus, such shortage in the rainfall in the Gulf region which is coincided with the high rate of evaporation in most of the days of the year with the presence of salt water, would make most of the lands as dry and very highly saline, reaching high values of electrical conductivities of the soil saturated extracts, ECe (about 200 milliSiemens / cm) in salt marshes, Sabkhas, coastal line and even in some inland areas [2-4]. The main source of salinity at the coastal line is from the saline water of the Gulf, while the high values of ECe in the inland areas and Sabkhas are attributed to the intrusion of seawater into the underground waters [5].

The meteorological data in the State of Qatar that have been obtained from Doha (The capital of Qatar) airport for the last two decades confirmed the reality of aridity of the land (Table 1). Some reports have indicated that the rainfall in this region is irregular and variable in time and space and unpredictable. From the data reported by Batanouny [6], the average annual rainfall in Doha for 17 years was $78.1 \mathrm{~mm}$, this figure fluctuates between 0.4 $\mathrm{mm}$ in 1962 and $302.8 \mathrm{~mm}$ in 1964. The temperature records, on the other hand, show that not a single month has mean temperature below $17.1^{\circ} \mathrm{C}$, and the mean minimum temperature does not drop below $12.7^{\circ} \mathrm{C}$. The absolute maximum temperature in January is $30.7^{\circ} \mathrm{C}$ and the absolute minimum temperature is $3.8^{\circ} \mathrm{C}$, and there is never a danger of frost. Over the year, the maximum temperatures are recorded in July and August; however an exceptional highest record of air temperature (about $49^{\circ} \mathrm{C}$ ) at Doha was reported in June 1962.

The world meteorological organization (UN) and Hong Kong Observatory reports about the climatic records in the city of Doha have confirmed the above conclusions [7]. Also, considerable variations have been found in most parameters of the physical and chemical characteristics of soils including: soil texture, water content, $\mathrm{pH}$ of the soil extracts and ECe; 
EC of the saturated soil extracts (Table 2). Such variations in those parameters are more obvious in ECe; which accompanied with the variation in $\mathrm{Na}^{+}$and $\mathrm{Cl}^{-}$ions content in those soils. In fact, the data have shown that the main elements that could cause salt stress in such soils are $\mathrm{Na}^{+}$and $\mathrm{Cl}^{-}$in addition to other cations like $\mathrm{Ca}^{+}, \mathrm{Mg}^{+}$and $\mathrm{K}^{+}$.

\begin{tabular}{|l|l|l|l|}
\hline Climatic elements & Annual values & $\begin{array}{l}\text { Months of lowest } \\
\text { values }\end{array}$ & $\begin{array}{l}\text { Months of highest } \\
\text { values }\end{array}$ \\
\hline Average temp. $\left({ }^{\circ} \mathrm{C}\right)$ & 27 & Jan: 17 & Jul-Aug: 35 \\
\hline Average max. temp. $\left({ }^{\circ} \mathrm{C}\right)$ & 31 & Jan: 20 & Jun-Jul: 40 \\
\hline Average min. tem. $\left({ }^{\circ} \mathrm{C}\right)$ & 22 & Jan: 13 & Jul-Aug: 30 \\
\hline Absolute max. temp. $\left({ }^{\circ} \mathrm{C}\right)$ & 47 & Jan - Feb: 32 & May-Aug: 47 \\
\hline Absolute min. temp. $\left({ }^{\circ} \mathrm{C}\right)$ & 1 & Jan: 1 & Jul: 23 \\
\hline Average rainfall $(\mathrm{mm})$ & 81 & Jun-Oct: 0 & Feb: 20 \\
\hline Average morning $\mathrm{RH}(\%)$ & 71 & Jun: 52 & Feb-Dec: 82 \\
\hline Average afternoon $\mathrm{RH}(\%)$ & 43 & Jun: 28 & Dec: 54 \\
\hline Average wind speed $(\mathrm{km} / \mathrm{h})$ & 20 & Sep-Oct: 14 & Jun: 27 \\
\hline
\end{tabular}

RH: Relative Humidity

Table 1. Climatic data of Doha city. Average annual values, average monthly lowest values, and average monthly highest values. Data of 17 years [5].

The above meteorological conditions and soil properties could be involved strongly to the features of the harsh environment in the region, and ultimately could have had major impact on the biodiversity and distribution of wild life in Qatar. Moreover, the shape, topography, geological structure and petrographic composition of the landscape are additional factors affecting the life of plants, as well as other living organisms [6]. Thus, from geographic point of view and climate conditions, Qatar is considered as hot subtropical desert with saline flats $[5,8]$.

\begin{tabular}{|l|l|}
\hline Parameters & Properties \\
\hline Soil texture & Sandy - Sandy clay loam \\
\hline Absolute water content $(\%)$ & $2.2-25.7$ \\
\hline Soil water content $(\%$ field capacity) & $7.9-65.9$ \\
\hline $\mathrm{pH}($ soil extract) & $6.6-8.4$ \\
\hline $\mathrm{ECe}\left(\mathrm{dSm}^{-1}\right)$ & $4.2-195.0$ \\
\hline $\mathrm{Na}^{+}\left(\mathrm{mg} \mathrm{l}^{-1}\right)$ of soil extract & $186-726$ \\
\hline $\mathrm{K}^{+}\left(\mathrm{mg} \mathrm{l}^{-1}\right)$ of soil extract & $60-108$ \\
\hline $\mathrm{Ca}^{2+}\left(\mathrm{mg} \mathrm{l}^{-1}\right)$ of soil extract & $63-113$ \\
\hline $\mathrm{Mg}^{2+}\left(\mathrm{mg} \mathrm{l}^{-1}\right)$ of soil extract & $34-82$ \\
\hline $\mathrm{Cl}^{-}\left(\mathrm{gl}^{-1}\right)$ of soil extract & $2.0-344$ \\
\hline
\end{tabular}

Table 2. The physical and chemical properties of soil samples collected from Doha area [9]. 


\section{The wild plants and adaptations}

Qatar is a small country with more than $4 / 5$ of its boundary surrounded by a coastline (Figure 1), and the combinations of many environmental factors including drought and salinity, and high evapo-transpiration, irradiance, and temperatures do not allow many plants to grow and survive in this region. The flora of Qatar has been placed into one of five main habitat groups [10]: (1) xerophytes of rock and gravel deserts where the conditions are very dry, (2) halophytes of saline areas such as salt marshes, coastal sands, sabkhas and oolitic sands, (3) xerophytic species grow in natural silt and sand depressions where water retention is higher than those purely xerophytes, (4) species adapted at deep sand where water is available under the surface, and (5) species receiving artificial irrigation such as farms, gardens and sewage ponds. Also, the coastal line has been classified into five halophytic plant communities: (1) mangrove intertidal community, (2) low salt marsh coastal community, (3) high salt marsh coastal community, (4) sandy coastal community, and (5) sandy-rocky coastal community [5]. The coastline of the State of Qatar encompasses unique ecosystem of vegetated sand beaches alternating with bays of aquatic halophytes and mangroves, followed inland by members of some families like chenopodiaceae, which are considered as halophytes and/or xerophytes. These plants have various morphological and anatomical modifications, and physiological and biochemical characteristics that could have contributed to their adaptation to the harsh environment in this region [9].

The checklist of plants in the State of Qatar has been reviewed many times, some reports [11] listed 213 species, while others [12] gave a list of 260 species, then the monograph of Batanouny [6] listed 301 species in 207 genera and 55 families. Recently, Norton and his colleagues [10] have increased the list of wild plants to nearly 400 species of which about 270 species are likely to be truly native. Some other references can be found in the last publication to updating the checklist of the wild plants in the Gulf region and in the State of Qatar. Most of these plants have been recognized as either xerophytes or halophytes; well adapted to dry and/or saline environments.

\subsection{Xerophytic plants}

Many plants at the coastal line and throughout the Qatari land are characterized as xerophytes, include: Cyperus conglomeratus, Oligomeris linifolia, Helianthemum lipii, Tetraena qatarense, Ochradenus baccatus and many others. These plants have various mechanisms to cope with drought and water stressed soils

\section{(A) Drought - Escaping xerophytes}

These plants germinate, grow, and flower within a short period of time after fairly heavy rainfall. They produce seeds before the dry season, and therefore, they resist dry season during the seed stage $[13,14]$. Examples of such plants: Polycarpaea spicata and Senecio desfontanei. Almost all ephemerals that germinate and grow in the desert after the summer rainfall are $\mathrm{C} 4$ plants, while plants that germinate after the autumn rainfall are $\mathrm{C} 3$ plants [13]. Most escaper plants survive the dry period in the desiccation - tolerant seed stage. 
Some efforts have been made to develop crop plants that can complete life cycle in a very short period of time, to avoid the dry season. Genetic hybridization and selection of some barley cultivars are among these efforts [15-17].

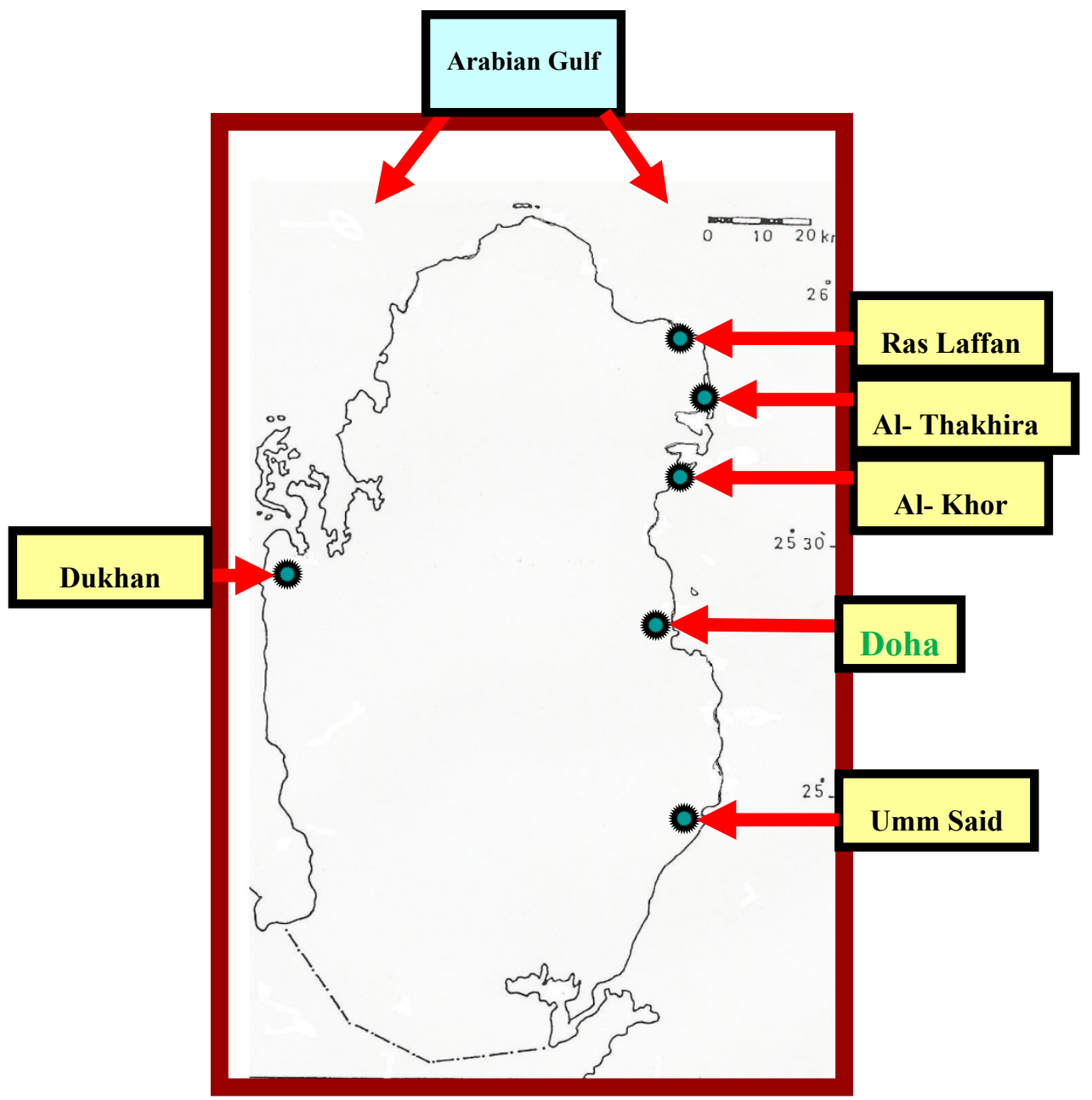

Figure 1. A map of Qatar showing the main cities and locations.

\section{(B) Drought avoidance}

These plants maintain favorable water content when exposed to external water stress. Drought avoidance is largely morphological-anatomical in nature. Two secondary mechanisms to avoid drought are considered here:

a. Water conservation: many plants can conserve water through the following adaptations: 
1. Morphology and behavior of stomata: stomata are differing in plant species in their number and distribution on both surfaces of the leaf, size, shape and behavior. These features are species-specific characteristics, and vary with the adaptation to stress conditions. In Cyperus conglomeratus, stomata appear only on the abaxial surface of the leaves and these stomata are sunken [18]. Moreover, most plants living in the desert areas or saline soils close their stomata during periods of osmotic stress except CAM (Crassulacean Acid Metabolism) plants. However, many plants have special physiological and biochemical features to cope with the harsh environments [19-21]. Data from glycophytes have revealed considerable reduction in the stomatal conductance with salinity [22]. In this respect, it should be understood that stomatal closure may help maintain the water balance inside the plant. Thus, stomatal closure can be considered as an adaptation characteristic that plants have in various degrees under conditions of osmotic stress [22-24]. Cyperus conglomeratus exhibits C4 metabolism and this characteristic might allow the plant to maximize rates of photosynthesis by sustaining stomatal opening [25].

2. Increased cuticle thickness by increasing the surface lipid: the cuticle of plants under osmotic stress may become more thickened than those living under normal conditions (well irrigated or / and non-saline) $[19,22,26]$. The thickened cuticle is observed in many of these plants like Cyperus conglomeratus and Tetraena qatarense [18].

3. Decreased transpiring surface: the reduction in the leaf area is a common response to osmotic stress, and could be a main reason behind the reduction in the total transpiration rate in most plants [22, 27]. In fact, the reduction of leaf area at stressed growth conditions has been considered as a complex response and can be seen as an adaptation feature to reduce the water lost by transpiration process [28]. Some plant species in the Qatari flora like Ochradenus baccatus showed great reduction in the size of leaves to reduce the transpiring surface. In some other plants, rolling, folding, or shedding of leaves are possible methods of drought avoidance mechanisms in many desert plants [26]. Aeluropus lagopoides is another example of wild plants having some morphological modifications to cope with dry soils which include leaves linear; lanceolate with small blades ending in sharp rigid points [4]. These plants might have green stems to increase the photosynthetic efficiency under the severe environmental conditions [29].

4. Root adaptation: plant roots can contribute effectively to the drought avoidance mechanism by three ways: (a) restricting the root surface and decreasing its permeability to water, (b) quick development of roots to absorb rain water and disappear soon after soil dries, and (c) roots can reduce transpiration by high resistance to water $[15,30]$. High Root / Shoot ratio, on the other hand, has been considered as a trait of a plant having drought avoidance mechanism $[19,31]$, Cyperus conglomeratus is a good example of such trait (Fig. 2) which helps withstand water stress by two ways: (1) less water is needed for the top, (2) exploring larger volume of soil.

5. Water storage: many plant species show succulence characteristics (Fig. 3); such plants could have water cells in stems, leaves and roots, which might confer avoidance mechanism against drought and water shortage. CAM plants are good example of how 


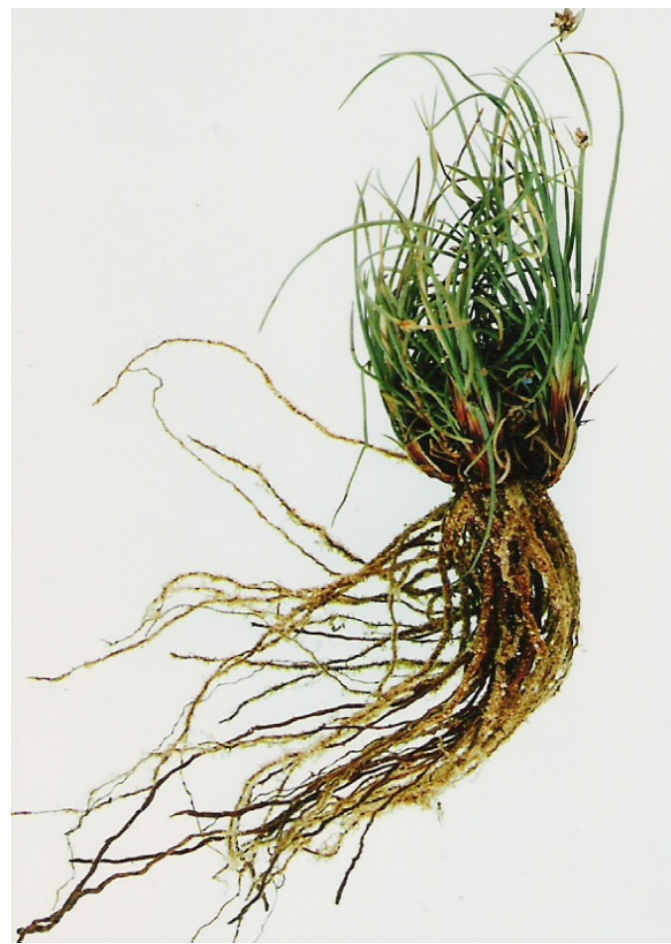

Figure 2. Cyperus conglomeratus has high root / top ratio.

plants can conserve water by closing stomata during the day to avoid water loss, and open them during the night for $\mathrm{CO}_{2}$ fixation [32]. The flora of Qatar includes many succulent plants some of which exhibit CAM characteristics. The following species have been recognized as CAM plants: Mesembryanthemum nodiflorum, Cyperus conglomeratus, Euphorbia granulate, Erodium laciniatum, Portulaca oleracea and may be many others; these plants seem to have high water use efficiency associated with metabolic pathways that enable them to survive such environmental conditions [33, 34]. Some CAM criteria like diurnal oscillation of titratable acidity, malic acid content and succulence have been studied in three native plants of the flora of Qatar like Salsola baryosma, Anabasis setifera, and Tetraena qatarense. It was concluded that A. setifera is a constitutive CAM plant while S. baryosma and T. qatarense are inducible CAM plants [35]. The study of Mazen [36] on Portulaca oleracea ( $\mathrm{C}_{4}$ plant) may show two different behaviors concerning CAM characteristics, these are CAM-expressing and non CAM-expressing, and the induction of CAM-like characteristics in this plant was accompanied by increased activity and synthesis of phosphoenolpyruvate carboxylase (PEPC). Mesembryanthemum nodiflorum, the slender ice plant, is a succulent annual that is native to southern Africa, and introduced to many parts of the world. It favors saline and degraded soils of the agricultural regions, and it has the ability to switch from $C_{3}$ photosynthesis to CAM model during its growth [37]. Oligomeris linifolia, on the other hand, is not a CAM plant 
in spite of its succulence characteristic and its ability to store water in different plant parts (Fig. 4). This species has been considered as a desert species suspected as halophyte. Its life form was considered as Sub-Fruticose Chamaephytes, erect fruit shoot at base [38]. It grows in various habitats, including disturbed areas and saline soils, in deserts, plains, coastline, and other places. It is a fleshy annual plant, producing several erect, ribbed stems 35 to 45 centimeters in maximum height. Although these plants are considered as xerophytes, they might have also well adapted to saline environments, since they are living in soils of high salinity levels [4].

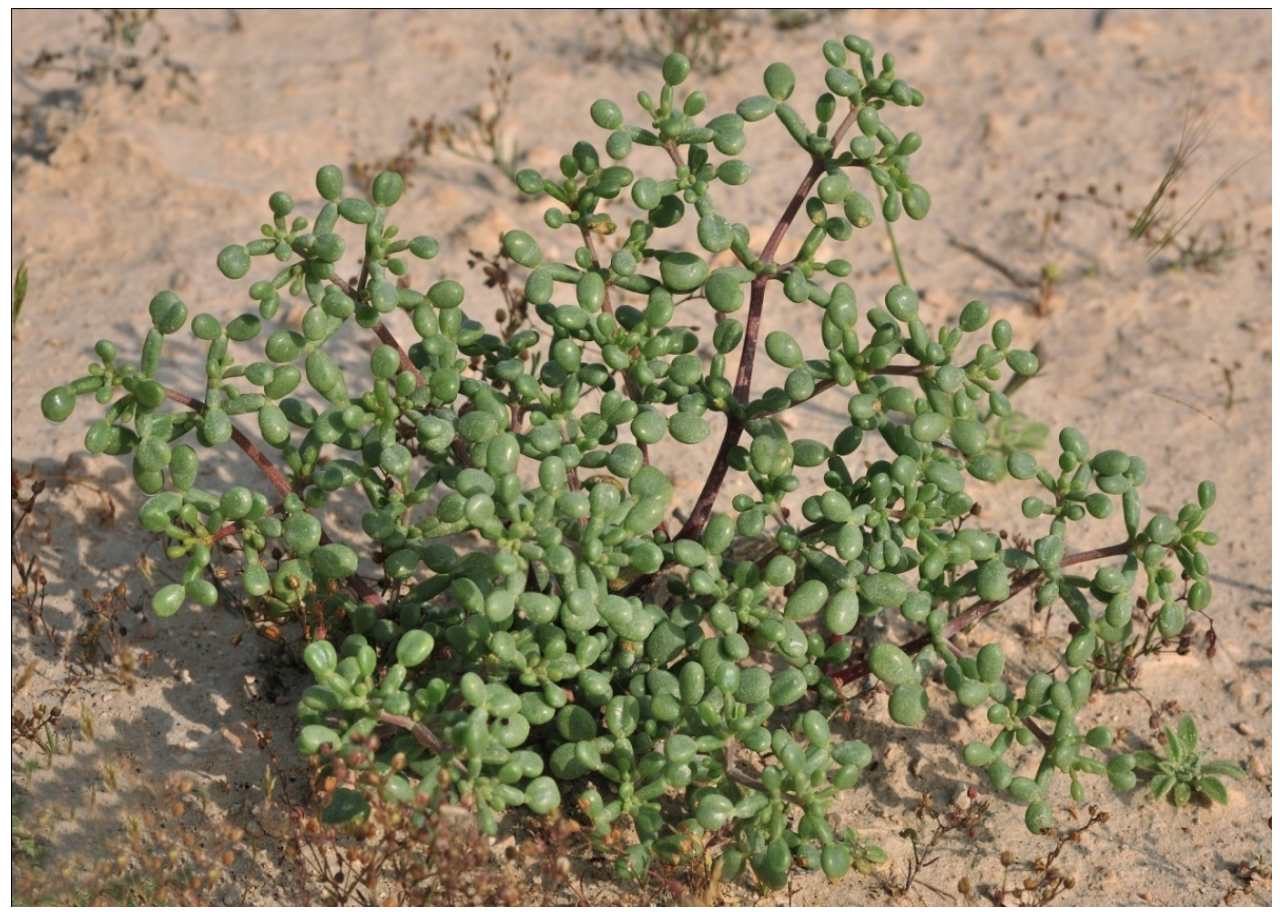

Figure 3. Branches of Tetraena qatarense with the fleshy leaves and woody stems.

b. Accelerated water absorption by water spenders: some plants can improve water uptake and content under drought by producing extensive roots or intensive fibrous root system to increase the active root surface area. Helianthemum lipii is a good example of a plant species having roots growing in the deeper soil layers toward the water table (Fig. 5). Also, some plants have high root / top ratio such as Cyperus conglomeratus (Fig. 2) which helps to cope with drought as mentioned before $[15,19,26]$.

\section{(C) Drought tolerance}

Plants can tolerate drought (water stress) by two main mechanisms: (a) Dehydration avoidance. (b) Dehydration tolerance. Plants living in the State of Qatar are resistant to drought not only because of the morphological characteristics as avoidance mechanism, but 
also by osmotic adjustment $[15,39]$ through accumulation of substantial amounts of organic and inorganic solutes like proline, glycinebetaine, sugars and inorganic ions to cope with soil of severe water shortage [3, 40-42]. Plants such as Tetraena qatarense and Ochradenus baccatus, are good examples of xerophytes having dehydration avoidance mechanism by accumulating solutes to withstand severe water stress [4]. Dehydration tolerance mechanism, on the other hand, includes some methods like avoidance of starvation strain by stomatal opening at low $\Psi_{\mathrm{w}}$, uncoupling of photosynthesis from transpiration, low respiration rate and other secondary mechanisms include: tolerance of starvation strain, avoidance of protein loss, and tolerance of protein loss [15]. Understanding these secondary mechanisms needs extensive and deep investigation in the plants covered in this review.

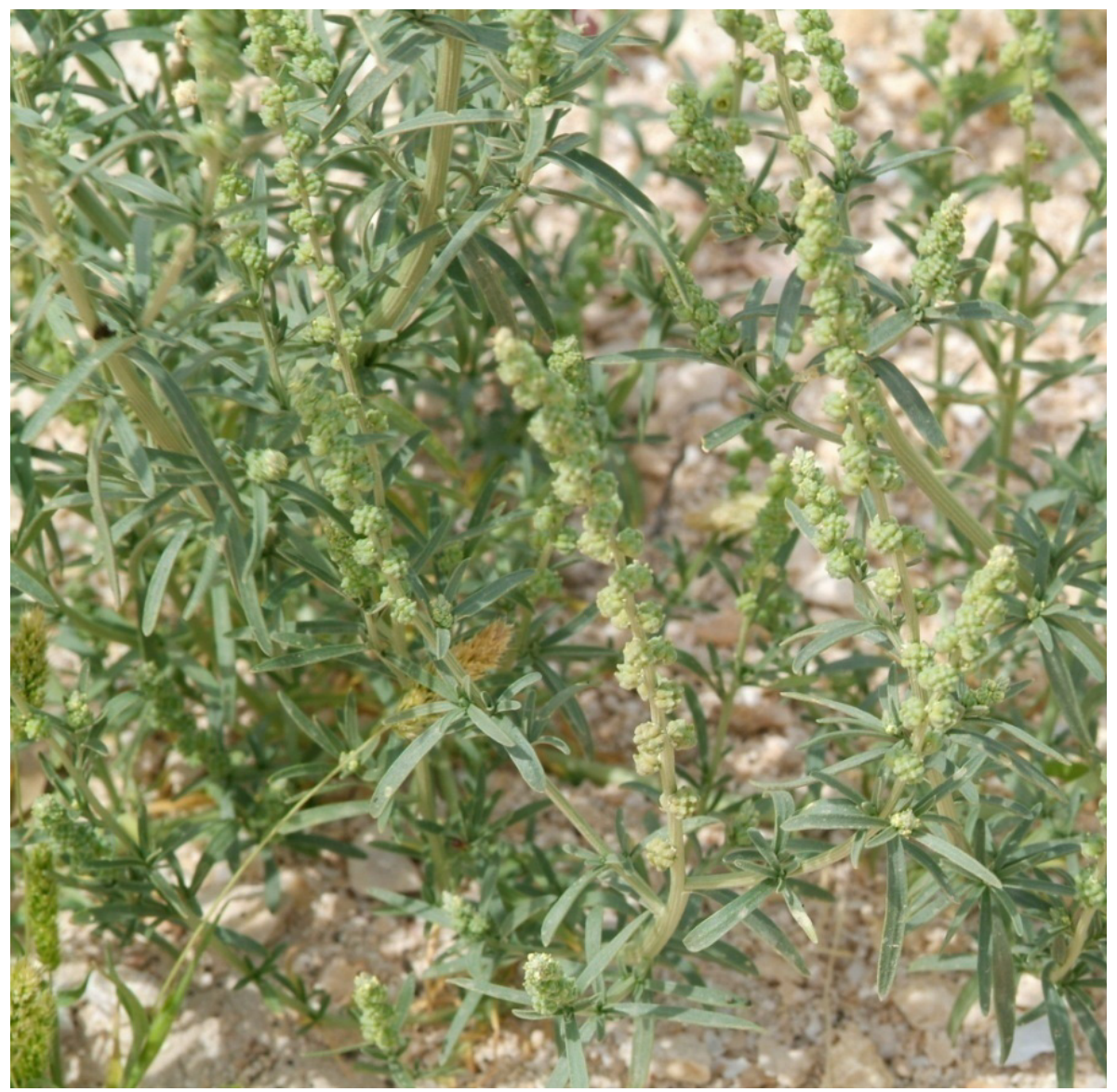

Figure 4. Oligomeris linifolia habit. 


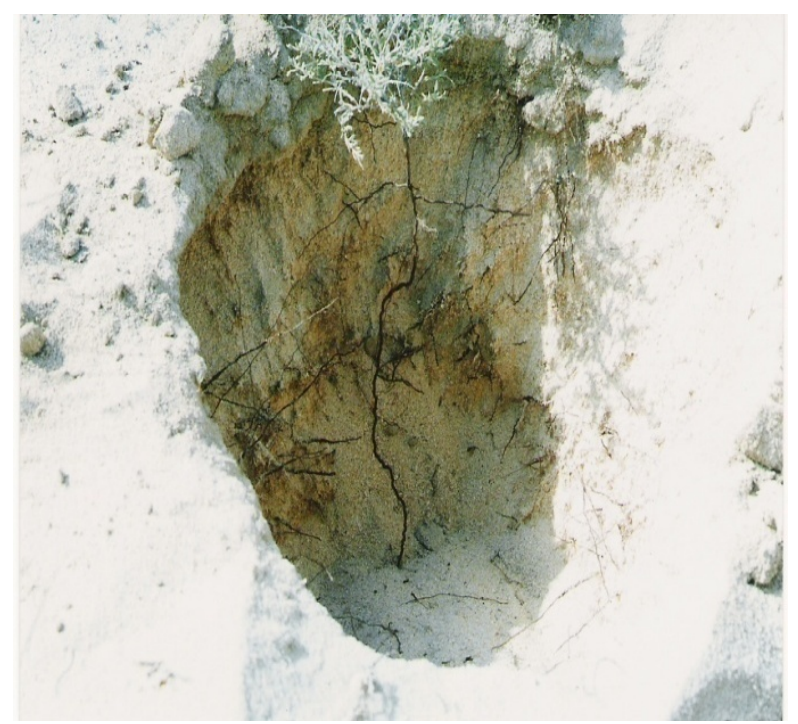

Figure 5. Some plants have roots growing in the deeper soil layers toward the water table, Helianthemum lipii.

\subsection{Halophytic plants}

Halophyte plants in Qatar are living near the coastal line, and in other inland areas like Subkhas, including some species of the genera Anabasis, Arthrocnemum, Atriplex, Avicennia, Halocnemum, Halopeplis, Limonium, Salsola, Seidlitzia, Suaeda and may be many others. These plants have two main mechanisms to cope with saline environments: (a) Avoidance mechanisms, (b) Tolerance mechanisms [9, 15, 26, 41, 43].

\section{(a) Avoidance mechanisms}

These mechanisms involve structural and physiological adaptations to minimize salt concentrations in the cells or physiological exclusion by root membranes. Plants can use one or more of the following secondary mechanisms to avoid salt stress at their environment: exclusion, extrusion and dilution.

i. Exclusion mechanism: plants having such mechanism may exclude ions at different locations along plant organs: (a) at the surface of the roots (b) between shoot system and root system, and (c) between leaves and petioles or sheaths. The best example of exclusion mechanism at the root surface was found in Date Palm trees (Phoenix dactylefera), which seems excluding $\mathrm{Na}^{+}$and $\mathrm{Cl}^{-}$from the root, by having a barrier at the root surface, since the uptake of $\mathrm{Na}^{+}$and $\mathrm{Cl}^{-}$was not proportional to the concentration of these ions in the external solution. The efficiency of exclusion increases with increasing salinity in the growth medium, and as a result, the accumulation of $\mathrm{Na}^{+}$and $\mathrm{Cl}^{-}$in the tissue was not much greater at high than at low salinity levels, and there were no visible symptoms of salt injury $[15,44]$. Halophytes and may be many glycophytes 
exclude ions from leaves to stems or roots [20,38]. Some reports [45] described the avoidance mechanism in the mangroves (Avicennia marina), by retaining low internal salinity in stems and leaves by means of salt excluding mechanisms in the roots. Leaves of this plant are grey and hairy at the lower surface where most secretion occurs, while the above surface is shiny green, glabrous with some salt glands. These salt glands play significant role in the internal balance and regulation of ions $[9,46]$. In glycophytes, there are two examples from Mexican wheat plants, in which exclusion of $\mathrm{Cl}^{-}$ions to the sheaths can be considered as a regulatory mechanism in these plants to avoid $\mathrm{Cl}^{-}$ accumulation in the leaves. Also, salt sensitive cultivars, like Yecora, failed to exclude $\mathrm{Na}^{+}$to the root systems as compared to salt resistant cultivars, like Cajeme, [22]. Moreover, salt exclusion may occur at the intracellular levels, and salt resistance can be attributed to the maintenance of ions homeostasis in the cytoplasm [47].

ii. Salt extrusion: it is an active process to excrete extra salts from the epidermal hairs or salt glands of leaves of some halophytes such as Limonium axillare and Atriplex spp. Some specialized structures called salt glands or salt bladders are found in leaves of those plants to regulate the extra salts inside the plant body [43]. Salt glands found in Limonium axillare are composed of (4-10) cells which are entirely covered by cuticle which seals the gland from the rest of the plant except for small gaps on the leaf mesophyll side, salts are deposited on the leaf surface through holes on these glands, and in mangroves (Avicennia marina), salts are excreted from the upper surface of leaves [46], and the excreted solutions exceed the $\mathrm{NaCl}$ concentration of seawater of about 10 times $[38,45,48]$. Salt Bladders are found in Atriplex, which are comprised of two cells: stalk cell and bladder cell [20,49]. Salt glands are found also in many other halophytes like Aeluropus lagopoides, Tamarix spp. and may be in other plant species [9, 50, 51]. These salt glands could regulate the secretion of salts from leaves to keep their concentrations at low levels and ultimately to maintain ion homeostasis in the plant body.

iii. Salt dilution: some halophytes can dilute the accumulated ions in plant tissues to keep cytoplasmic salinity below toxic levels. Succulence is feature of the whole plant body or may be confined to stems and / or leaves. These plants are considered as salt includers. Some succulent halophytes living in Qatar include Halopeplis (Fig. 6), Suaeda (Fig. 7) and Tetraena (Fig. 3). Halophytes having dilution mechanism are characterized by: (1) thickening in leaves, (2) elongation of cells, (3) higher elasticity of cell wall, (4) smaller relative surface areas, (5) decrease in extensive growth, and (6) high water content per unit of surface areas $[38,52]$. In fact, most halophytes accumulate inorganic ions that are found in abundance in the environment like $\mathrm{Na}^{+}$and $\mathrm{Cl}^{-}$, and such accumulation is accompanied with a decline in $\mathrm{K}^{+}$content [41]. In addition to the ion accumulation and succulence phenomenon, shedding of old salt-saturated leaves is found in plants having dilution mechanism to avoid the damage caused by extra salt accumulation [53].

\section{(b) Tolerance mechanisms}

Osmoregulation or osmotic adjustment has been considered as a main secondary mechanism to tolerate salt stress. Osmotic adjustment can be defined as maintenance of positive water balance between soil environment and plant tissues, by lowering their plant 


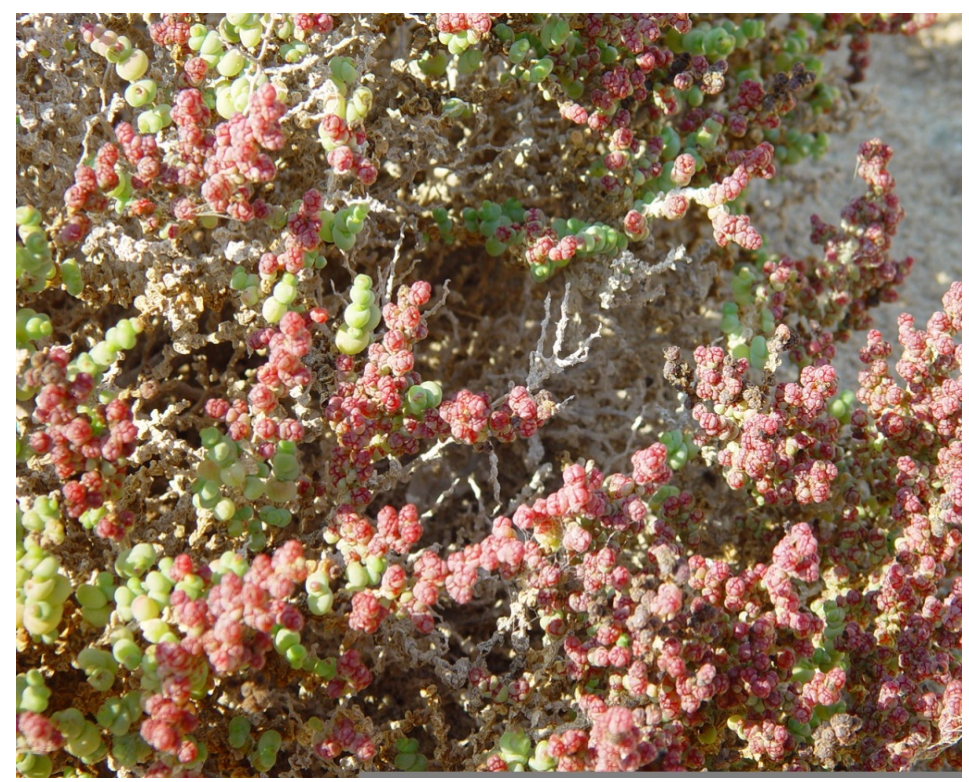

Figure 6. Halopeplis perfoliata habit.

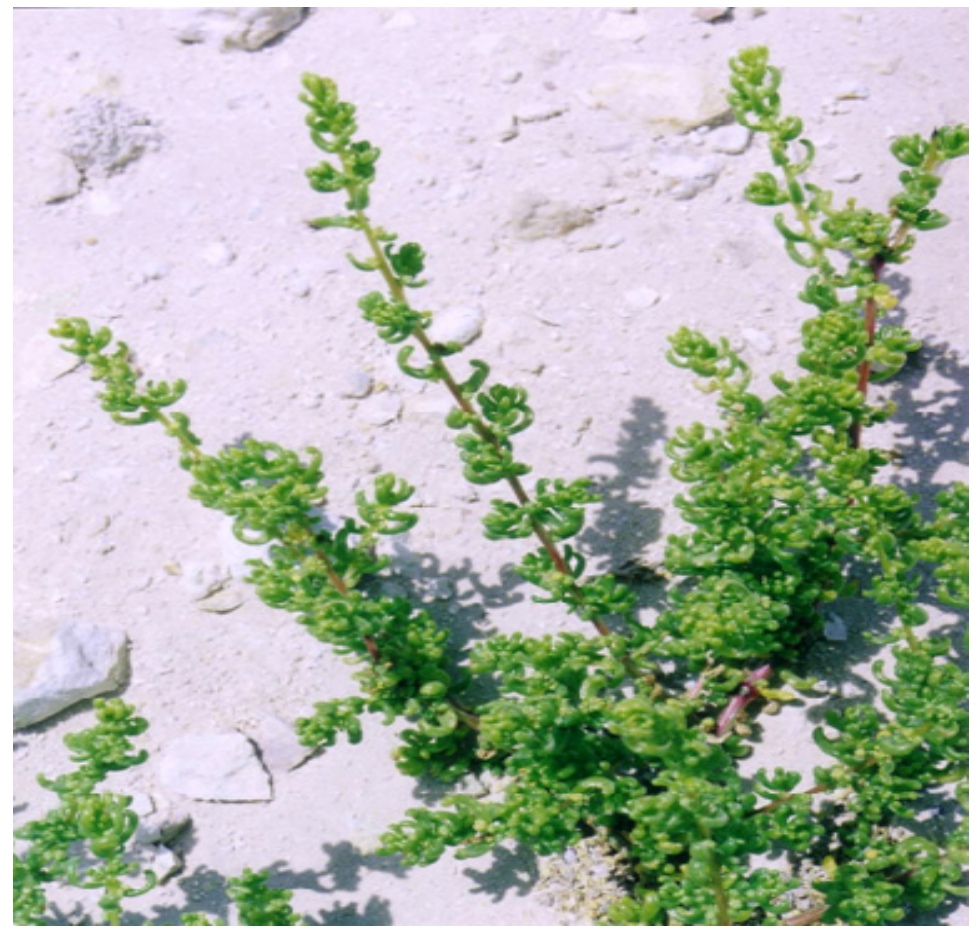

Figure 7. Suaeda aegyptiaca shoots. 
water and solute potentials (Table 3). In halophytes, this mechanism involves physiological and biochemical adaptations for maintaining protoplasmic viability as cells accumulate inorganic ions mainly $\mathrm{Na}^{+}, \mathrm{Cl}$, followed by $\mathrm{Ca}^{2+}, \mathrm{K}^{+}$and $\mathrm{Mg}^{2+}$, and other organic solutes to achieve osmotic adjustment $[41,46,54]$. However, these ions may be sequestered in vacuoles leaving relatively low ions in the cytoplasm. Some authors [55] reported in their review that crops including cereals tolerate $\mathrm{NaCl}$ by excluding $\mathrm{Na}^{+}$from the transpiration stream as well as sequestration of $\mathrm{Na}^{+}$and $\mathrm{Cl}^{-}$in the vacuoles of root and leaf cells, and promote other physiological processes like faster growth rates and longer duration by maintaining high concentrations in $\mathrm{K}^{+}$despite the osmotic stress of the salt outside the roots [28, 56]. Organic solutes like glycinebetaine, proline, sugars, polyols etc., may accumulate in the cytoplasm to achieve osmotic balance inside the cells, and therefore play a pivotal role in plant cytoplasmic osmotic adjustment. Thus, salt tolerance in these plants can be attributed mainly to the fact that these plants accumulate low-molecular-mass organic compounds (compatible solutes) [57-60].

\begin{tabular}{|c|c|c|c|c|c|}
\hline \multirow{2}{*}{$\begin{array}{c}\text { Salt stress of growth } \\
\text { medium } \\
\left(\mathrm{NaCl}, \mathrm{molm}^{-3}\right)\end{array}$} & $\begin{array}{c}\text { Osmotic potential of growth } \\
\text { medium } \\
\left(\Psi_{\mathrm{s}, \mathrm{MPa})}\right.\end{array}$ & \multicolumn{2}{|c|}{ Roots } & \multicolumn{2}{|c|}{ Leaves } \\
\cline { 3 - 7 } & -0.05 & Cajeme & Yecora & Cajeme & Yecora \\
\hline 0 & -0.25 & -0.50 & -0.49 & -0.92 & -0.98 \\
\hline 50 & -0.44 & -0.62 & -0.62 & -1.17 & -1.27 \\
\hline 100 & -0.61 & -0.72 & -0.69 & -1.46 & -1.51 \\
\hline 150 & -0.80 & -0.74 & -1.85 & -1.86 \\
\hline
\end{tabular}

Table 3. Osmotic adjustment (MPa) in two Mexican wheat cultivars exposed to salt stress [22].

These solutes, as non-toxic cytoplasmic osmotica, that play major roles in the physiology and biochemistry of plant cells and have contributed in the process of osmotic adjustment, maintaining turgor and hydration of cellular microstructures, as sources of some carbon and nitrogen skeletons, and osmoprotectants [61, 62]. As osmoprotectants, these compounds tend to be excluded from the hydration sphere of proteins and stabilizing the folded protein structure [63-65], maintaining plasma membranes, protecting the transcriptional and translational machineries and intervening in the process of refolding of enzymes as molecular chaperones [66, 67]. Moreover, compatible compounds like proline and glycinebetaine can induce the expression of certain stress-responsive genes, including those for enzymes that scavenge reactive oxygen species [68].

\section{Microorganisms associated with wild plants}

Higher plants are normally colonized by microorganisms, which include bacteria, fungi, algae or protozoa. Microorganisms interact with plants because plants offer a wide diversity of habitats including the (a) phyllosphere (aerial plant part), (b) rhizosphere (zone of influence of the root system), and (c) endosphere (internal transport system). Interactions of epiphytes, rhizophytes or endophytes may be detrimental or beneficial for either the microorganism or the plant, and may be classified as neutralism, commensalism, synergism, mutualism, amensalism, competition or parasitism [69]. Symbiosis is a relationship that both 
microorganisms and plants get benefits, and nitrogen fixation and mycorhizae are good examples of such relationships. The plant provides carbon materials to support the growth of microorganisms, while the latter promote plant growth by enhancing minerals uptake e.g. nitrogen and phosphorus (70). A mini review by [71], about the symbiosis relationship between desert plants and Mycorrhizae, indicated that desert ecosystems were not different from other ecosystems in the presence of mycorrhizae. These mycorrhizae might affect nutrient acquisition such as $\mathrm{P}, \mathrm{N}, \mathrm{Fe}, \mathrm{Zn}, \mathrm{K}$ and others. They also increase plant adaptation to abiotic stresses and some other stresses. Commensalism is another example that various chemicals are secreted from various plant parts like roots and leaves to stimulate the growth of microorganisms. Some other microorganisms can cause some diseases to plants, and this happens when the natural defense systems of the plant are ineffective. In fact, plants may limit microbial penetration by having a thick cell wall and other structural barriers like the cuticle layer that restrict infection. Moreover, the defense system in the plant includes the secretion of gums and some chemicals to limit the invasion of microorganisms [72]. The following are some examples of microorganisms associated with various plants from the Qatari environment and the perspectives of using these organisms to solve the outstanding problems of health, economy and food security.

\subsection{Mangrove}

Qatar is home to Avicennia marina; it is known as the grey mangrove or white mangrove trees, communities of which form several forests around Qatar shores. These mangrove swamps are home to a wealth of life. The largest area of mangroves - and the oldest - can be found around Al Thakhira and Al Khor. Other mangrove areas in Qatar originate from fairly recent plantings by the government.

Decomposers play an important role in the cycling of material and the flow of energy through an ecosystem. In the mangrove ecosystem, bacteria and fungi break down dead organic matter, such as mangrove leaves. One teaspoon of mud from a mangrove forest is estimated to contain 10 billion bacteria. These bacteria break down the leaf litter and provide nutrients for the other organisms that live in the mangrove swamp [73, 74]. This forms the basis of the food chain in the mangrove swamp. The nutritional value of the leaves is increased by the work of decomposers. Mangrove ecosystems are an important natural resource that should be protected. The detritus generated by the mangroves is the base of an extensive food web that sustains numerous organisms of ecological and commercial importance. Furthermore, mangrove ecosystems provide indispensable shelter and nurturing sites for many marine organisms. The well-being of mangroves is dependent on the diverse, and largely unexplored, microbial and faunal activities that transform and recycle nutrients in the ecosystem. Conservation strategies for mangroves should consider the ecosystem as a biological entity [75]. Despite numerous studies on the biogeography, botany, zoology, ichthyology, environmental pollution, and economic impact of mangroves, little is known about the activities of microbes in mangrove waters and sediments. An effort must be made for further studies on microbial activities in mangrove ecosystems and their impact on the productivity of the ecosystem. 
Various types of microorganisms are found around the mangrove habitats. For example, diverse cyanobacterial communities reside on leaf, root litter, live roots, and often form extensive mats on the surrounding sediments; many of these communities are capable of fixing atmospheric nitrogen. Many genera widespread in these habitats including Oscillatoria, Lyngbya, Phormidium and Microcoleusare, and as heterocystous genera, Scytonemais common in some areas [76]. The filamentous cyanobacterium Microcoleus sp.was isolated and inoculated on to young mangrove seedlings. Such cyanobacterial filaments colonize the roots of mangrove by gradual production of biofilm [77]. Also, bacteria may influence the mangrove ecosystem directly; they contribute inevitably in the recycling of nutrients [78]. Many potential bacteria were isolated from mangrove ecosystem such as nitrogen-fixers, phosphate solubilizers, photosynthetic anoxygenic sulfur bacteria, methanogenic and methane oxidizing bacteria, which are involved in efficient nutrient recycling [79]. Also bacteria and fungi that either produce antibiotics [80, 81] or resistant to antibiotics were isolated from mangrove ecosystem [82, 83].

\subsection{Halophytes}

Salt-tolerant microorganisms can grow in habitats containing high concentrations of salts. The natural environments for salt-tolerant microbes may be similar to those of the halophytic angiosperms. The chemical analysis of the materials excreted by the epidermal glands of halophytes revealed the presence of mineral elements and some organic compounds, such substances might be a source of nutrition to the microorganisms living on the plant body [84]. A study on the desert plants of Egypt [85] indicated that the fungal species inhabiting the surface of senescent leaves of the succulent halophyte Zygophyllum album L. appeared to be adapted to stressful conditions of their microhabitats, namely high convective heat, dry conditions and high salt content of their leachates. In the study of [84] on some halophyte species growing at the Qatar North East coast showed that the total bacterial count in the rhizosphere was higher than in the non-rhizosphere soil. Moreover, the bacterial counts in the soil supporting the plant species of the coastal zone were higher than those in the soil of the inland zones. Also, Gram- positive cocci predominated in the isolates from rhizosphere and non-rhizosphere soil, and the isolates with white colonies color predominated in the rhizosphere than from phyllosphere since low colonization of bacterial cells were found on the aerial parts that have high contents of mineral ions due to the activity of salt glands in most Halophytes. Also, the bacterial counts were higher on the green parts of the plant than on the senescent parts, since the latter might have accumulated high concentrations of mineral ions as a mechanism to exclude salt to the aged parts of the plants compared to the growing ones. Moreover, the phyllosphere of the green and senescing parts were characterized by the predominance of Gram-positive bacilli and by the low percentage of isolates producing colored colonies. The general conclusion that can drawn from various published studies that soil environment and phyllosphere of halophytes support the growth of bacteria which seemed to have various mechanisms to deal with the harsh environments like salt marshes and sabkhas. In fact, bacteria are the most abundant inhabitants of the phyllosphere and the most colonists of leaves. On the other hand, the bacterial flora of the above ground differs substantially from that at the 
subterranean plant surfaces. For example, the pigmented bacteria which are rarely found in the rhizosphere, and laminate leaf surfaces and solar radiation affect the ecology of the phyllosphere and promote bacteria to produce pigments as sun screen and will not damage the cell components. There are two general strategies for osmo-adaptation of prokaryotes like bacteria under osmotic stress conditions: (1) accumulation of inorganic ions, and (2) accumulation of low molecular weight organic molecules. In the first strategy, osmotic equilibrium is maintained which involves the selective influx of potassium $\left(\mathrm{K}^{+}\right)$and chloride $\left(\mathrm{Cl}^{-}\right)$into the cytoplasm. The extremely halophilic archaea of the family Halobacteriaceae and the bacterium Salinibacter ruber as well as the moderately halophilc bacteria of the order Haloanaerobiales accumulate enormous quantities of $\mathrm{K}^{+}$and $\mathrm{Cl}^{-}$. The second strategy of osmoadaptation, on the other hand, involves the accumulation of a limited range of lowmolecular-weight organic solutes. These include many compounds which are called compatible solutes including amino acids like proline, glycinebetaine, simple sugars, polyols, and their derivatives. Some microorganisms, such as hyper/thermophiles, utilize a combination of both strategies by accumulating negatively charged compatible solutes [86] and potassium. Great deals of attention have been paid to proline and glycinebetaine as compatible solutes accumulated as a result of salt or water stress. Relatively few prokaryotes are capable of de novo synthesis of these compounds. The intracellular concentrations of these solutes can be regulated in accordance with the external salt concentration, provide microorganisms with a large degree of flexibility and the possibility to adapt to a wide range of salt concentrations. However, energetically the production of massive amounts of such solutes can be costly.

\subsection{Prosopis cineraria}

Prosopis cineraria is the only species that grow rarely in desert of Qatar. The genus Prosopis contains around 45 species of spiny trees and shrubs found in the subtropical regions of Americas, Africa, Western Asia, and South Asia. They often thrive in arid soil and are resistant to drought, on occasion developing extremely deep root systems. The microbiology analyses of P. cineraria trees in Qatar [87] showed that the bark was colonized by large number of bacteria as compared to the leaves. Gram- positive cocci and spore forming bacilli bacteria are characterized by thick cell wall that is comprised of peptidoglycan (amino acid polypeptide and a sugar), and the isolated bacilli genus were spore forming that can be survive in hot, dry conditions, and high irradiation with limited damage to the cell. These are the most dominant epiphytic form on both leaves and bark. The pigmented bacteria, red yellow, and orange, were isolated from leaves and bark which exposed to long duration of light, that pigments well keep the bacterial cells undamaged and resistant to irradiation. The observed high content of organic matter, soil nutrients, clay and moisture in the sub-canopy locations of $P$. cineraria trees significantly affect the richness of the below canopy sites [87]. The bacterial soil populations in the rhizosphere are higher than the non-rhizosphere sits and the lowest bacterial count occurred in the outer canopy soil. Moreover, the presence of plant litter, animal droppings together with the already existed soil chemical nutrients in the sub canopy positions of $P$. cinerearea trees possibly increase the enrichment of these patches. 
One of the best documented spatial patterns of nutrient distributions in arid and semiarid ecosystems are the "islands of fertility" associated with shrubs and trees [88].

The components of rhizosphere system which include microorganisms, plant and soil interact with each other in a way so that the rhizosphere is distinguished from the bulk of the remaining soil. The activity of root microorganisms is affected by soil environmental factors or by environmental factors operating indirectly through the plant. Moreover, root microorganisms can affect the plant and plant nutrient uptake, directly by colonizing the root and modifying the soil environment around the root. Bacterial growth is stimulated by a vast range of organic materials released from plant roots, which include carbohydrates, vitamins, amino acids and enzymes. Organic acids and lipids reduce the $\mathrm{pH}$ of the rhizosphere and also have a role in the chelation of metals [89]. However, direct benefit to the plant growth is not easy to demonstrate but the activities essential to plant growth, including mineralization and nitrogen fixation by free-living bacteria are concentrated in the rhizosphere. Miscellaneous compounds including volatile substances can physiologically stimulate or inhibit organisms. There are many factors affecting the release of organic compounds include plant species and cultivars, age and stage of plant development, light intensity and temperatures, soil factors, plant nutrients, plant injury, and soil microorganisms. Factors such as light, moisture, and temperature can all cause changes in plant metabolism and the rhizosphere effect. In summary, rhizosphere populations are dependent on many diverse interacting factors. In heavy textured soils oxygen become limiting, resulting in reduced rhizosphere populations compared to the coarse-textured soils.

\section{Microorganisms and the outstanding problems}

Modern and innovative approaches to solve the problems facing mankind of health, economy and food security rely mainly on living organisms that can be grown and breed easily in the lab. Great achievements in the biotechnology have been accomplished using microorganisms like bacteria, fungi and viruses. For example, Rhizobium has been used as bio-fertilizer, mycorhizae were used to promote the plant growth by uptake minerals from soil, Bacillus thuringiensis is to control the pest, Ti plasmid of Agrobacterium in genetic engineering and the field is opined for more molecules and compounds (proteins, enzymes, UV-absorbents, etc) extracted from those microorganisms that are adapted to survive the hostile environmental in the Gulf region. Also, in Qatar there have been a large number of bacteria strains that have been isolated from soils and being tested against different pathogens affecting economic plants (data not published). Such approach might be a good alternative to the classic one of using chemicals. B. thuringiensis strains are aerobic, Grampositive found broadly distributed in the Qatari soil; produce a protein that has been used to control insect population. Another challenge to make clean environment in Qatar, bioremediation is being tested in Qatar to degrade and remove contaminants from wastewater and soil. Bioremediation processes rely mainly on the activity of those microorganisms to get rid of organic pollutants including polycyclic aromatic hydrocarbons (PAHs). This topic will be discussed latter with phytoremediation of contaminated soils and waters. In Qatar, information about the organic degrading bacteria from soil are scarce. 
However, some recent serious works have identified some of these bacteria from different Qatari polluted soils using modern techniques [90, 91]. Bioremediation has obvious advantages over physicochemical remediation methods due to several merits: cost-effective, convenient, complete degradation of organic pollutants and no collateral destruction of the site material or its indigenous flora and fauna. Nutrients such as nitrogen and phosphorus can be added to the soil to improve the effectiveness of land farming alone. These nutrients can boost the population of naturally occurring microbes. Numerous soil bacteria, including Pseudomonas sp. have the ability to degrade organic contaminants so some remediation will occur. Even with this augmentation, however, larger and more recalcitrant compounds generally are not remediating at satisfactory rates. The concept of using plants for remediation of organic pollutants emerged a few decades ago with the recognition that plants were capable of metabolizing many toxic compounds. There are many studies suggesting the usefulness of plant-microbe systems in the bioremediation of residual chemicals [92-95]. The presence of Plant growth-promoting rhizobacteria (PGPR) in rhizosphere can enable plants to achieve high levels of biomass in contaminated soils despite extreme conditions. Generally, PGPR function in three different ways: (i) by synthesizing particular compounds for the plants, (ii) facilitating the uptake of certain nutrients from the environment and (iii) preventing the plants from diseases [96]. The common traits of growth promotion includes production or changes in the concentration of plant hormones such as auxin, gibberellins, cytokinins and ethylene [95]. Bioaugmentation is a method to improve degradation and enhance the transformation rate of xenobiotics by the seeding of specific microbes, able to degrade the xenobiotics of interest. Extensive degradation of petroleum pollutants generally is accomplished by mixed microbial populations, rather than single microbial species. Many microbes are described to have the genetic tools to mineralize recalcitrant pollutants such as PAHs, chlorinated aliphatics and aromatics, nitroaromatics and long-chain alkanes. These microbes can be wild-type isolates and genetically modified strains equipped with catabolic plasmids, containing the relevant degradation genes $[93,94]$.

\subsection{Restoration of habitats}

Many habitats are disappearing from several locations in the Gulf region in general and in the State of Qatar in particular, with the completion of constructions and urban development due to the great expansion caused by the establishment of infrastructure of the extraction and industry of oil and gas [4, 97]. Also, cconsiderable achievements being accomplished in Qatar in the development of land and establishment of roads, high ways, new buildings and many facilities as preparations to host major political, sport and social activities in the next decade. In fact, during the last decade and with the beginning of these developments, many reports and studies have warned the decision makers and scientists that the natural wildlife in the Gulf area is at real risk and facing serious threat due to the human and industrial activities [41, 46, 98]. Such threat and damage to the environment could be deepened if these activities and industrial constructions are not coupled by any studies on habitat destruction, fragmentation or disturbances, and restoration and conservation measures to maintain the natural habitats. There is fear that before knowledge is obtained on the flora and fauna and their ecophysiological aspects, these habitats will be lost. Therefore, some serious measures should 
be taken urgently including vegetation maps and monitoring exercises to document the state of the vegetation [99]. Such efforts should include ecophysiological aspects of the wild life, as prerequisite for ecological restoration $[5,100]$.

Looking at the changes in Doha, many habitats in this city are being demolished and / or threatened with the completion of construction of new buildings and facilities to comply with the great expansions in the industrial and urban sectors and responsibilities of hosting a number of activities in the coming years. These changes that are taking place at the coastal areas and inland as well; are lacking appropriate impact assessment and restoration plans [98]. One example of these changes is well demonstrated in a location near Qatar University, the details of changes were discussed in some reports and papers [41]. Restoration of endangered habitats is urgently required to maintain and sustain wild life since many scientists and decision makers in the State of Qatar are aware of the serious threats facing the natural habitats especially at the coastal line and other parts of inland areas $[4,97]$. Such threats had been neglected for long period of times in the past, and there is growing worries about the diminishing natural sources of land and good quality water for agriculture and the scanty seasonal rains as well as all types of wild life. It would be very useful for the local authorities to take the initiatives to avoiding the consequences of putting the environment at real risk due to these changes in all sectors of life in the State of Qatar. Therefore, successful ecological restoration and maintaining healthy environment are based on the following main principles: (1) Information, (2) Problems, (3) Plans, (4) Solutions, (5) Monitoring.

\subsection{Information}

Successful restoration programs need information about the environment and wildlife which includes inventory of fauna, flora and microorganisms, their morphological characteristics and the mechanisms of adaptation. In Qatar, there has been cconsiderable information documented in a number of publications covering the above topics $[2,5,6,10$, 101-106]. Recording and documenting the existing wild life and their ecophysiology in their natural habitats have been considered as a first important step toward conducting successful ecological restoration. For example, Ecology and Flora of Qatar, a monograph written by Batanouny [6], covered the ecological features of Qatar, the landforms, the prevailing climatic conditions, soils and resources and their effects on the plant life, description of the vegetation and the widespread plant communities, and the flora of Qatar which includes description of 301 species. Another monograph worth to be reported here prepared by Abulfatih and his colleagues [5]: Vegetation of Qatar, which recorded the state of the plant communities and ecosystems in the state of Qatar especially at the locations of oil and gas industry. Such efforts were considered essential for monitoring the future state of natural habitats and very valuable to biologists, environmentalists, naturalists, agriculturists as well as the decision makers and planners. Other published works, worth to be mentioned here, covered various topics of wild plants, horticultural plants, fungi and algae and their chemical constituents $[2,9,98,102,104,106-109]$.

During the last ten years some studies on the ecophysiology of wild plants in Qatar have shown that soil texture ranged between sandy to silty loam at the coastal line, while inland 
soils were sandy to sandy clay loam. The soils are dry, alkaline and highly saline, ECe ranged between 4 to $200 \mathrm{dSm}^{-1}$, and the most abundant ions in these soils and plants living in these soils are $\mathrm{Na}^{+}$and $\mathrm{Cl}^{-}$followed by $\mathrm{K}^{+}, \mathrm{Ca}^{2+}$, and $\mathrm{Mg}^{2+}$. Most plant species are halophytes, undershrubs and succulents, with xerophytes due inland around Doha [3, 41, 46]. Halophytes did not accumulate much proline, soluble nitrogen and photosynthetic pigments, however, xerophytes do contain much of these organic components [4].

\subsection{Problems}

Recognition of the problems facing human life in all aspects, like economy, agriculture, health and wild life has been considered as the first step to successful scientific solution programs to tackle these problems. The problems facing the wild life in the State of Qatar can be summarized as follows: (1) harsh environment in terms of drought, salinity and high temperatures have great impact on the agricultural economy and the plant wild life. Changes in the climate, evaporation of water due to extreme high temperatures and scarcity of rainfall, and the intrusion of seawater into the underground water are the main reasons behind such problems. Irrigation of crops in the Gulf region faces serious challenges because of limited water supply of good quality suitable for normal plant growth. Moreover, large areas of the Qatari land are suitable for agricultural purposes; however, these areas are not only suffering from water shortage but also facing a problem of continuous increasing salanization. Soil salinity reached levels that inhibit the growth and yield of most crop plants, (2) disappearance of many coastal and inland habitats due to enormous urban constructions in various areas especially in Doha city which are accompanied with industrial expansions is putting the environment at risk, threatening ecosystem services and biological diversity, (3) wastewater accumulation at the outskirts of Doha and other towns due to the industrial activities of gas and oil could have great impact on the human and wild life. Pollution caused by heavy metals and organic hydrocarbons of the wastewater may cause real threats to many sectors of economy, agriculture, health and wild life.

\subsection{Plans}

Scientists have paid great deal of attention to the problems facing the mankind after considerable technological progresses to provide effective solutions to those problems. In the State of Qatar, there is a widespread perception among scientists and officials about the hazardous effects of pollutants resulted from accumulation of wastewater produced during gas and oil industrialization. Many serious measures have been taken in eliminating or reducing the adverse impact of those activities through a number of regulations to support scientific researches about the consequences of the loss of many natural habitats as well as the accumulation of organic and inorganic pollutants. For example, gas companies have pledged to the Supreme Council for Environmental Nature Reserve (SCENR) to implement Environmental Impact Assessment (EIA) for any plan to change the natural habitats. EIA is defined as a process of evaluating the impact and consequences of a project on various aspects of human life in both beneficial and adverse. Two main types of research to restore 
and conserve endangered habitats in Qatar can be conducted: (1) restoration of habitats, (2) bioremediation of contaminated soils, water and air. Various types of organisms can be used like bacteria, fungi and plants. A process of using plants to remove contaminants from soils is called phytoremediation; which will be discussed below.

\subsection{Solutions}

Solutions of the environmental problems lie always in hands of scientists, the decision makers and the public. Using scientific approaches to solve the environmental problems to minimize the consequences of the new developments in the Gulf region have been strongly suggested, active and serious efforts should start with the recording and documenting the existing wildlife including plants and their ecophysiology under their natural habitats. Such efforts can be considered as a prerequisite for successful ecological restoration $[4,9,41,98]$. On the other hand, it would be very useful for the local authorities and the decision makers to take the initiatives to maintain the environment and solve the problems and easing the difficulties facing such efforts by: (1) implementing plans for restoration, (2) creating nature reserves to preserve the flora and fauna, (3) imposing laws that enforce the Environmental Impact Assessment (EIA) on oil and gas companies for any plans to change the natural habitats, (4) consulting research centers prior to any future construction plans, and, (5) activating scientific research for gene manipulation to maintain native plants. Halophytes and xerophytes living in these areas can be considered as good sources of salt-resistant and/or drought resistant traits from which genes can be transferred to crop plants $[3,9,41$, $97,110]$. The public, on the other hand, is the beneficiary or the victim of any environmental changes, and all the developments in all life sectors are reflected on this party. Therefore, to improve the awareness of conservation of natural habitats, educational materials should be enriched by various means like conferences, meetings, workshops, visits to some sites, as well as providing magazines, posters, pamphlets, films and videos.

\subsection{Monitoring}

Monitoring has been defined as collecting and analyzing of data to make the required and appropriate assessments of the performance success at various scales. In this concept such assessment might include modifications in the plans to conduct active amendments to solve the emerged problems and to build long-term public support to protect and restore habitats. All these efforts should be forwarded to the decision makers to take the appropriate measures. Thus, after the completion of environmental restoration, the establishment of long-term monitoring and resolving the arisen problems during that period. Supplement plans should be developed and ready for implementation to solve those emerged problems.

\subsection{Case study of habitat restoration}

The above five principles can be implemented in every successful ecological restoration plan, and the consecutive steps can be summarized as follows: 
(A) Pre-Restoration process: (1) describe the current condition of ecological resources, (2) use the possible methods to describe the history of the site, (3) review the literature and visit the site to hypothesize how the original system of the site worked, (4) determine the objectives of the restoration and specify the condition of the site in the future.

(B) The Restoration process: (1) develop and implement the plan to achieve the objectives, this includes identification of the schedule tasks, adopt the methods, estimate the cost and labour, and begin the restoration work, (2) monitor the steps of the implementation plan to assess the success of restoration.

(C) Post-Restoration process: (1) prepare reports and evaluate the success periodically, (2) revise the plan and make the possible modifications to achieve the restoration objectives, (3) make education efforts to exploit the success of the restoration process.

In Qatar, little works have been done concerning the restoration of endangered habitats. However, a pioneer project to restore part of the coastal vegetation habitat was carried out during pipeline installation at Ras Laffan area. The details of this project can be found in the report of Al-Ansi and his colleagues [98], and was considered as a successful attempt to restore part of the coastal habitat. There are many reasons behind such success: (1) this project was a simple and inexpensive method to restore the vegetation, (2) the phases were implemented according to the plan, (3) in the pre-construction phase, the site was surveyed and the existing topography, vegetation density, floristic composition, and wildlife were recorded and documented in detail, (4) mitigation procedures were developed to minimize the impact of the construction activities in the project site, (5) tracking was undertaken to follow the progress of construction in the site, (6) after completing the construction, the project site was re-visited to ensure that the top soil was returned to its original position, and (7) the project site was inspected to monitor the restoration and growth of coastal vegetation.

\section{Phytoremediation of contaminants}

Contaminants enter into the environment in various ways, including direct leak or through accidents during transport or during waste disposal from storage sites or industrial facilities $[111,112]$. Bioremediation process has been adopted as effective technique to remove, transfer, degrade and immobilize various types of pollutants from soil and ground water using living organisms including bacteria, algae and fungi. The term phytoremediation then used to refer to such process when plants and their associated microbes are used for environmental cleanup to deal with the organic and inorganic contaminants without the need to excavate them and dispose them elsewhere. The problems of contamination as a consequence of human and industrial activities are increasing. High levels of contaminants might have accumulated in the soil and urban areas near oil and gas facilities which cause a lot of damage to the environment and ecosystem. Most of the environmental contaminants are chemical of both organic and inorganic origins. Different phytoremediation mechanisms and methods have been recognized. The details of these processes can be found in many published reports and papers [113-117]. Phytoremediation is not a new technique to remove 
heavy metals or organic compounds from wastewater or contaminated soil. About 300 years ago some plants like Thlaspi caerulescens and Viola calaminaria were reported to accumulate high concentrations of heavy metals [118-120]. In the twentieth century, these efforts continued to add more plants that have the potential in removing toxic metals and organic compounds from soil and water. Many benefits have been reported of phytoremediation as compared to the conventional methods as follows: (1) less invasive and destructive, (2) less costs, (3) promote the biodiversity and enhance the restoration of the damaged habitats, (4) improve the environment components of water, soil and air, (5) reduce erosion by micrometeorological factors, (6) improve the general social life such as providing shade to buildings, decreasing energy consumption and reducing the carbon emitted from many sources [121].

Concerning the plant species growing in the State of Qatar that have been used in many studies of phytoremediation of pollutants from soils and waters elsewhere of the world included: (1) Typha domingensis Pers.: this plant has been used in phytoremediation studies to remove heavy metals from industrial wastewater and solution cultures [122, 123], (2) Phragmites australis: this species has been used in the phytoremediation of petroleumpolluted soils in China [11, 124], (3) Brassicaceae: members of this family are very important in phytoremediation of heavy metals [125-127], (4) Juncus rigidus Desf. members of the family Juncaceae might be used in the phytoremediation of contaminated soils [128], (5) Tamarix spp.: species of this genus had been used to produce wood by growing them in arid lands and irrigated them with salty effluent from desalinization plants or with recycled sewage [129], (6) Prosopis Juliflora: this tree can be used in phytoremediation of heavy metals $[130,131],(7)$ Medicago spp.: species of this genus like Medicago sativa have been used in phytoremediation of soil polluted with petroleum compounds [113]. Both species Medicago laciniata and medicago polymorpha are found within the flora of Qatar, and can be tested as an option in the phytoremediation, and (8) Glycine max has been successfully used in removing toxic petroleum products from contaminated soil [132]. More investigations are needed to increase the list of native plants that are efficient in removing pollutants from soil and water as expansion in the oil and gas industry and other human activities increased in the coming years. In Qatar, some serious research projects are being conducted to test some native plants to clean up soils and wastewater from organic and inorganic contaminants. Bioremediation (phytoremediation) processes have been considered as necessary and first step in successful ecological restoration of polluted habitats [133, 134].

\section{Genetic approach}

Since 1980 there have been serious and strenuous efforts by many scientists and researchers to develop crops with high resistance to the environmental stresses especially salinity and drought [135]. Since then great deal of achievements have been accomplished to identify many plants having some morphological, physiological and biochemical characteristics associated with the resistance to these abiotic stresses. Among these plants are wild plants and local varieties of some crops such as wheat, barley, rice and tomato [60, 136-144]. In Qatar and other Gulf States, native plants like halophytes and xerophytes deserve special attention, in addition to their economic and medicinal importance [106, 145], they could 
address important issues in biology and offer unique genetic pools to be used for gene technology programs leading to yield improvement of various crops under severe environmental stresses. Recent studies have concentrated on the native plants and to identify their critical salt or drought tolerance traits that could potentially be used in improving agricultural crops. Some reports [146] have compared Arabidopsis thaliana with 11 wild relatives in response to salinity. Major differences in some physiological traits including growth, water transport and ion accumulation were found, these differences can be exploited in the genetics of salt stress studies. Modern techniques that have been adopted to increase the resistance of crop plants to drought and salinity, including technologies of molecular biology, genetic engineering and tissue culture, have fruited in establishing solid basics to face the future challenges in the question of global food security [55, 110, 147-150].

Moreover, hopes are still in the minds of the decision makers and scientists to exploit the genetic bank in wild plants and / or genetically engineered plants to clean contaminated environments, and to deal with the pollution problems that arose due to the human activities and after the expansion in the industrial and urban sectors [151]. Striking successes have been achieved using genetic manipulation to improve the phytoremediation methods to remove pollutants from the environment as a step leading to the restoration of habitats [127]. Some reports [152] have indicated that using genetic engineering techniques is possible to improve some physiological characteristics in plants like uptake, transport, accumulation and tolerance of metals; such efforts could lead to create and develop transgenic plants have the ability to remove heavy metals from the growth medium. Thus, efforts using modern techniques and the identification of potentially genes for transformation of target plants could be promising approaches in improving the efficiency of these plants in the phytoremediation of contaminated environments. Some novel works worth to be mentioned here, some researchers [153] used chloroplast transformation to enhance the capacity of tobacco (Nicotiana tabacum) plant for mercury (Hg) phytoremediation, such technique may also have application to other metals that affect chloroplast function. Also, [128] have reported that wetland grasses and grass-like monocots can be changed genetically to improve their remediation potential. Plant species involved in these efforts are among those monocots genera in various families such as Poaceae, Cyperaceae, Juncaceae, and Typhaceae. Fulekar and his collaborators [154] have reported that plants such as Populus angustifolia, Nicotiana tabacum and Silene cucubalis have been genetically engineered to provide enhanced heavy metal accumulation characteristic as compared to the corresponding wild type plants. Other efforts in breeding plants having high biomass production and superior phytoremediation potential were considered as an alternative approach to deal with contaminants. The general productivity of plants is controlled by many genes, and genetic engineering techniques to implant more efficient accumulator gene into other plants have been suggested by many authors [115, 155]. Recently, some authors [156] in their review have concluded that transgenic plants and associated bacteria bring hope for a broader and more efficient application of phytoremediation for the treatment of organic compounds like polychlorinated biophenyls (PCBs). Genetic modification of plants may improve some phytoremediation mechanisms like phytoextraction, phytotransformation, etc, and also improve the bacterial efficiency in biodegradation of those 
organic compounds (rhizoremediation). The application of gene manipulation and the use of native plants that are metal tolerant and /or efficient in absorption and degradation of organic compounds should be accelerated and transferred from the experimental level to the field [157].

\section{Conclusions}

The ecophysiological studies of native plants that are adapted to various extreme environmental conditions like drought, salinity, high temperatures and contaminated environments are prerequisite to tackle the current problems facing mankind like food security, pollution and the endangered habitats. The State of Qatar and other Gulf States might have the preference over many other countries in the world to be leaders in the technological research to address the problems of restoration, phytoremediation and modern biological issues to deal with harsh environments. Being an Arab Gulf State, there are three basic elements to deal with the above problems: (1) the superior financial status which comes from the revenues of oil and gas industry, (2) the strong-willed of the scientists and decision makers. The universities in Qatar and other Gulf States and many established research centers have engaged and started actively with modern research to address various environmental problems, (3) the current native plants living in the Gulf States could be a good choice in the phytoremediation methods, and also might be good resources of traits from which genes can be manipulated and transferred to crop plants, or to develop efficient transgenic native plants in the phytoremediation processes of contaminated soil and water.

\section{Author details}

Bassam T. Yasseen* and Roda F. Al-Thani

Department of Biological and Environmental Sciences, College of Arts E Sciences, Qatar University, Doha, The State of Qatar

\section{Acknowledgement}

Authors would like to thank Professor Ekhlas M. Abdel-Bari, Environmental Studies Centre, Qatar University for providing the nice photographs of some wild plants from the Qatari habitats.

\section{References}

[1] Persian Gulf: http://www.emecs.or.jp/guidebook/eng/pdf/07persian.pdf. (accessed 28 ${ }^{\text {th }}$ September 2012).

[2] Abulfatih HA, Al-Thani RF, Al-Naimi IS, Swelleh JA, Elhag EA, Kardousha M. M., editors. Ecology of wastewater ponds in Qatar. Scientific and Applied Research Centre (SARC), University of Qatar, Doha, Qatar; 2002.

${ }^{*}$ Corresponding Author 
[3] Yasseen BT, Al-Thani RF. Halophytes and associated properties of natural soils in the Doha area, Qatar. AEHMS 2007; 10: 320 - 326, DOI: 0.1080/14634980701519462.

[4] Yasseen BT. Urban Development Threatening Wild Plants in Doha City-Qatar: Ecophysiology is a Prerequisite for Ecological Restoration. Journal of Plant Sciences 2011; 6 (3): 113 - 123.

[5] Abulfatih HA, Abdel-Bari EM, Alsubaey A, Ibrahim YM., editors. Vegetation of Qatar. Scientific and Applied Research Center (SARC), University of Qatar, Doha, Qatar; 2001.

[6] Batanouny KH., editor. Ecology and Flora of Qatar. Scientific of Applied and Research Centre (SARC), University of Qatar, Doha, Qatar; 1981.

[7] Wikipedia, the free encyclopedia. Doha: http://en.wikipedia.org/wiki/Doha. (Accessed $28^{\text {th }}$ September 2012).

[8] Meigs P., editor. World distribution of arid and semi-arid homo climates. In: Reviews of research on arid zone hydrology. Paris, Arid Zone Program, UNESCO; 1953. 1: p203 209.

[9] Abdel-Bari, EM, Yasseen BT, Al-Thani, RF. Halophytes in the State of Qatar. Environmental Studies Center. University of Qatar, Doha, Qatar, ISBN.99921-52-98-2; 2007.

[10] Norton J, Abdul Majid S, Allan D, Al Safran M, Böer B, Richer R., editors. An Illustrated Checklist of the Flora of Qatar. United Nations Educational, Scientific and Cultural Organization, UNESCO Office in Doha. Qatar Foundation. MAERSK OIL QATAR AS. Doha, Qatar; 2009.

[11] Obeid M. Qatar - study of the natural vegetation. FAO AGO QAT/74/003; 1975.

[12] Boulos L, editor.. 1978. Materials for a flora of Qatar. Webbia 1975; 32(2) :369-396.

[13] Turner NC. Drought resistance and adaptation to water deficit in crop plants. In: Mussel H, Staples RC. (eds.) Stress physiology in crop plants, Wiley and Sons (Interscience), New York; 1979. p343-372.

[14] Ludlow MM. Strategies in response to water stress. In: Kreeb HK, Richter H, Hinkley, TM. (eds.) Structural and functional response to environmental stresses: Water shortage. SPB Academic Press, The Netherlands; 1989. p. 269-281.

[15] Levitt J., editor. Responses of plants to environmental stresses. Vol. II. Water, Radiation, Salt, and Other Stresses. Academic Press, New York, London; 1980.

[16] Omara MK. Selection of early maturing barley with improved response to drought stress. Aust. J. Agric. Res. 1987; 38: 835-845.

[17] Chaves MM, maroco JP, Pereira JS. Understanding plant response to drought - from genes to the whole plant. Functional Plant Biology 2003; 30: 239 - 264.

[18] Zaman S, Padmesh S. Leaf anatomical adaptations of selected Kuwait's native desert plants. European Journal of Scientific Research (2009); 37 (2): 261 - 268.

[19] Yasseen BT., editor. Physiology of water stress in plants. The University Press, University of Mosul, Mosul, Iraq; 1992.

[20] Nilsen ET, Orcutt DM., editors. Physiology of plants under stress. Abiotic Factors. John Wiley \& Sons, Inc., New York; 1996.

[21] Taiz L, Zeiger E., editors. Plant Physiology, $5^{\text {th }}$ Ed. Sinauer Associates, Inc., Publishers, Sunderland, Massachusetts USA. ISBN 978-0-87893-866-7; 2010. 
[22] Yasseen BT. An analysis of the effects of salinity on leaf growth in Mexican wheats, PhD thesis. The University of Leeds, Leeds, UK; 1983.

[23] Gulzar S, Ajmal Khan M, Ungar IA, Liu X. Influence of salinity on growth and osmotic relations of Sporobolus ioclados. Pak. J. Bot. 2005; 37 (1): 119 - 129.

[24] Gulzar S, Ajmal Khan M. Comparative salt tolerance of perennial grasses. In: Ajmal Khan, M, Weber, DJ. (eds.) Ecophysiology of high salinity tolerant plants. Springer, The Netherlands; 2006. p. 239 - 253.

[25] Brown GM., editor. Vegetation ecology and biodiversity of degraded desert area in north eastern Arabia. Kuwait University, Final report SO 073, Department of Biological Scienecs, Kuwait. pp. 15 - 16; 2001.

[26] Larcher W., editopr. Physiological plant ecology. Eco-physiology and stress physiology of functional groups, $4^{\text {th }}$ ed. Springer, Berlin; 2003.

[27] Hoffman GJ, Shalhevet J, Meiri A. Leaf age and salinity influence on water relations of pepper leaves. Physiol. Plant. 1980; 48 (3): 463 - 469.

[28] Yasseen BT, Abu-Al-Basal MA, Alhadi FA. An analysis of leaf growth under osmotic stress. J. Plant Sciences 2010; 5: 391- 401.

[29] Byrne, K. (1998). Plant adaptation to dry environment. Bio Factsbeet. No. 29. http://www.scribd.com/doc/8303899/29-xerophytes. (Accessed 28th September 2012)

[30] Price AH, Cairns JE, Horton P, Jones HG, Griffiths H. Linking drought-resistance mechanisms to drought avoidance in upland rice using a QTL approach: progress and new opportunities to integrate stomatal and mesophyll responses. J. Exp. Bot. 2002; 53 (371): 989-1004.

[31] Wright GC, Smith RCG, McWilliam JR. Differences between two grain sorghum genotypes in adaptation to drought stress. I. Crop growth and yield responses. Aust. J. Agr. Res. 1983; 34: 615 - 626.

[32] Lee JS. Stomatal opening mechanism of CAM plants. J. Plant Biol. 2010; 53: 19-23.

[33] Koch KE, Kennedy RA. Crassulacean Acid Metabolism in the Succulent C4 Dicot, Portulaca oleracea L Under Natural Environmental Conditions. Plant Physiology 1982; 69: 757-761.

[34] Masrahi YS, Al-Huqail AA, Al-Turki TA, Sayed OH. Differential altitudinal distribution and diversity of plants with different photosynthetic pathways in arid southern Saudi Arabia. Australian Journal of Basic and Applied Sciences 2011; 5(6): 3643.

[35] Mazen AMA. Crassulacean Acid Metabolism criteria shown by three species from flora of Qatar. QRS Repository 2011; Volume 2011; 2427. http://www.qscience.com/doi/abs/10.5339/qnrs.2011.2427.

[36] Mazen AMA. Changes in levels of phosphoenolpyruvate carboxylase with induction of Crassulacean acid metabolism (CAM)-like behaviour in the C4 plant Portulaca oleracea. Physiologia Plantarum1996; 98(1): 111-116.

[37] Clayton HAC, Barrett-Lennard EG, Ludwing M. Induction of CAM in the slender ice plant, Mesembryanthemum nodiflorum, by salinity and low water treatments. American Sciety of Plant Biologists. Photosynthesis \& Respiration 2012; http://abstracts.aspb.org/pb2009/public/P45/P45025.html. 
[38] Khan MA, Qaiser M. Halophytes of Pakistan: Characteristics, distribution and potential economic usages. In: Khan MA, Kust, GS, Barth HJ, Böer B. (eds.) Sabkha Ecosystems. Vol. II. Springer, Netherlands; 2006. p 129-153.

[39] Turner NC, O’ Toole JC, Cruz RT, Yambao EB, Ahmad S, Namuco OS, Dingkuhn M. Response of seven diverse rice cultivars to water deficit. II. Osmotic adjustment. Leaf elasticity, leaf extension, leaf death, stomatal conductance and photosynthesis. Field Crop Res.1986; 13: 273 - 286.

[40] Dingkuhn M, Cruz RT, O'Toole JC, Turner NC, Doerffling K. Responses of seven diverse rice cultivars to water deficits. III. Accumulation of abscisic acid and proline in relation to leaf water-potential and osmotic adjustment. Field Crops Research 1991; 27 (1-2): $103-117$.

[41] Yasseen BT, Abu-Al-Basal MA. Ecophysiology of Chenopodiaceae at the Coastline of Arabian Gulf-Qatar: Possible Destruction and Prespective Conservation. European Journal of Scientific Research 2010; 39 (1): 90 - 104.

[42] Aziz I, Gul B, Gulzar S, Khan MA. Seasonal variations in plant water status of four desert halophytes from semi-arid region of Karachi. Pak. J. Bot. 2011; 43(1): 587 - 594.

[43] Orcutt DM, Nilsen ET., editors. Physiology of plants under stress. Soil and Biotic Factors. John Wiley \& sons, Inc. N.Y.; 2000.

[44] Aljuburi HJ, Al-masry HH. Effects of salinity and indole acetic acid on growth and mineral content of date palm seedlings. Fruits 2000; 55: $315-323$.

[45] Ungar IA., editor. Ecophysiology of vascular halophytes. CRC Press, Boca Raton; 1991.

[46] Yasseen BT, Abu-Al-Basal MA. Ecophysiology of Limonium axillare and Avicennia marina from the coastline of Arabian Gulf-Qatar. Journal of Coastal Conservation: Planning and Management 2008; 12(1):35-42, DOI: 10:1007/s11852-008-0021-z.

[47] Glenn EP. Mechanisms of salt tolerance in higher plants. In: Basra AS, Nasra RK (eds) Mechanisms of environmental stress resistance in plants. Harwood Academic Publishers, Amsterdam; 1997. p 83 - 110.

[48] Joshi A J. Physiological studies on some halophytes. PhD thesis. Saurashtra University, India; 1979.

[49] Fahn A., editor. Plant anatomy, 3 $3^{\text {rd }}$ Ed. Pergamon Press, Oxford; 1990.

[50] Salama FM, El-Naggar SM, Ramadan T. Salt glands of some halophytes in Egypt. Phyton (Horn Austria) 1999; 39 (1): 91-105.

[51] Ahmed MZ, Gilani SA, Kikuchi A, Gulzar S, Ajmal Khan M, Watanabe KN. Population diversity of Aeluropus lagopoides: A potential cash crop for saline land. Pak. J. Bot. 2011; 43(1): 595-605.

[52] Longstreth DJ, Nobel, PS. Salinity effects on leaf anatomy. Consequences for photosynthesis. Plant Physiology 1979; 63 : 700 - 703.

[53] Albert R. Salt regulation in halophytes. Oecologia (Berl.) 1975; 21: 57-71.

[54] Flowers TJ, Yeo AR. Ion relations of plants under drought and salinity. Aust. J. Plant Physiol 1986; $13: 75$ - 91.

[55] Munns R, James RA, Läuchli A. Approaches to increasing the salt tolerance of wheat and other cereals. J. Exp. Bot. 2006; 57 (5): 1025-1043. 
[56] Abu-Al-Basal MA, Yasseen BT. Changes in Growth Variables and Potassium Content in Leaves of Black Barley in Response to NaCl. Brazilian J. Plant Physiology 2009; 21 (4): $261-270$.

[57] Wyn Jones RG, Storey R, Leigh RA, Ahmad N, Pollard A. A hypothesis on cytoplasmic osmoregulation. In: Marre E, O Cifferi O. (eds) Regulation of Cell Membrane Activities in Plants. Elsevier, Amsterdam; 1977. p 121-136.

[58] Greenway H, Munns R. Mechanisms of salt tolerance in nonhalophytes . Annu. Rev. Plant Physiol. 1980; $31: 149-190$.

[59] Flowers TJ. Physiology of halophytes. Plant \& Soil 1985; 89: 41-56.

[60] Hasegawa PM, Bressan RA, Zhu J - K, Bohnert HJ. Plant cellular and molecular responses to high salinity. Annu. Rev. Plant Physiol. Plant Mol. Biol. 2000; 51: 463 - 499.

[61] Khan MA, Ungar IA, Showalter AM, Dewald HD. NaCl - induced accumulation of glycinebetaine in four subtropical halophytes from Pakistan. Physiol. Plant. 1998; 102 : $487-492$.

[62] Sakamoto A, Murata N. Genetic engineering of glycinebetaine synthesis in plants: current status and implications for enhancement of stress tolerance. Journal of Experimental Botany 2000; 51: $81-88$.

[63] Jolivet Y, Larher F, Hamelin J. Osmoregulation in halophytic higher plants: The protective effect of glycine betaine against the heat destabilization of membranes. Plant Sci. Letts 1982; 25: 193-201.

[64] Low PS. Molecular basis of the biological compatibility of nature's osmolytes. In: Eds. Gills R, Gilles-Baillien, M. (eds) Transport processes, iono-and osmoregulation. Springer-Verlag, Berlin; 1985. p 469-477.

[65] Xing W, Rajashekar CB. Glycine betaine involvement in freezing tolerance and water stress in Arabidopsis thaliana. Environmental \& Experimental Botany 2001; 46 (1): 21 - 28.

[66] Chen TH-H, Murata N. Enhancement of tolerance to abiotic stress by metabolic engineering of betaines and other compatible solutes. Current Opinion in Plant Biology 2002; 5: 250-257.

[67] Park E-J, Jeknic Z, Pino, M-T, Murata N, Chen TH-H. Glycinebetaine accumulation is more effective in chloroplasts than in the cytosol for protecting transgenic tomato plants against abiotic stress. Plant, Cell \& Environment 2007; 30: 994 - 1005.

[68] Chen TH-H, Murata N. Glycinebetaine protects plants against abiotic stress: mechanisms and biotechnological application. Plant, Cell \& Environment 2011; 34 (1): 120.

[69] Montesinos E. Plant-associated microorganisms: a view from the scope of microbiology. Int. Microbiol. 2003; 6: 221-223. DOI 10.1007/s10123-003-0141-0.

[70] Barton LL, Northup DE., editor. Microbial Ecology. Wiley-Blackwell; 2011.

[71] Al-Whaibi MH. Desert Plants and Mycorrhizae (A mini-review). J. Pure Appli. Micro. 2009; 3(2): 457-466.

[72] Sigee DC., editor. Bacterial Plant Pathology; Cell and Molecular Aspects. Cambridge University Press; 1993.

[73] Mahasneh AM. Bacterial Decomposition of Avicennia marina L. Leaf Litter from Al-Khor (Qatar -Arabian Gulf). J. Biol. Sci. 2001; 2(11): 717-719. 
[74] Mahasneh AM. Heterotrophic Marine Bacteria Attached to Leaves of Avicennia marina L. Along the Qatari Coast (Arabia Gulf) .J. Biol. Sci. 2002; 2(11)740-743.

[75] Holguin G, Vazquez P, Bashan Y. The role of sediment microorganisms in the productivity, conservation, and rehabilitation of the mangrove ecosystems: an overview. Biol. Fertil. Soils.2001; 33:265-278.

[76] Hoffmann L. Marine cyanobacteria in tropical regions: diversity and ecology. Eur. J. Phycol. 1999; 34(4): 371-379.

[77] Toledo G, Yoav Bashan Y, Al Soeldner. In vitro colonization and increase in nitrogen fixation of seedling roots of black mangrove inoculated by a filamentous cyanobacteria. Cana. J. Micro. 1995; 41(11): 1012-1020.

[78] Holguin G, Vazquez P., Bashan Y. The role of sediment microorganisms in the productivity, conservation, and rehabilitation of mangrove ecosystems: an overview.Biol. Fertil. Soils.2001; 33:265-278. DOI 0.1007/s003740000319.

[79] Rueda-Puente E, Castellanos T, Troyo-Diéguez E, Díaz de León-Álvarez J, MurilloAmador B. Effects of a nitrogen-fixing indigenous bacterium Klebsiell apneumoniae on the growth and development of the halophyte Salicornia bigeloviias a new crop for saline environments. J. Agron. Crops Sci., 2003; 189: 323-332.

[80] Baskaran R, Vijayakumar R, Mohan P, M. Enrichment method for the isolation of bioactive actinomycetes from mangrove sediments of Andaman Islands, India. Malay. J. Micro. 2011; 7(1): 26-32.

[81] Gupta N, Das S, Basak, UC. Useful extracellular activity of bacteria isolated from Bhitarkanika mangrove ecosystem of Orissa coast. Malay J. of Micro. 2007; 3(2): 15-18.

[82] Ramesh S, Manivasagan P, Ashokkumar S, Rajaram G, Mayavu P. Plasmid Profiling and Multiple Antibiotic Resistance of Heterotrophic Bacteria Isolated from Muthupettai Mangrove Environment, Southeast Coast of India. Curr. Res. Bact. 2010; 3 (4): 227-237.

[83] Jalal KCA, NurFatin UT, Mardiana MA, Akbar John B, Kamaruzzaman YB, Shahbudin $\mathrm{S}$, Nor Omar M. Antibiotic resistance microbes in tropical mangrovesediments in east coast peninsular, Malaysia. Afri. J. Micro. Res. 2010; 4 (8): 640-645.

[84] ] Fahmy GM, Al-Thani RF., editors. Ecology of Halophytes and their Bacterial Inhabitants in the Coastal Salt Marsh of Al-Dhakhira, Qatar.Environmental Studies Centre (ESC), University of Qatar, Doha, Qatar; 2006.

[85] Ouf SA. Mycological studies on the angiosperm root parasite Cynomoriumcoccineum L. and two of its halophytic hosts. Biologia Plantarum 1993; 35: 591-692.

[86] Brown AD. Microbial water stress. Bacteriolo. Rev.1976; 40: 803-846.

[87] Al-Thani RF. Microbiological Analysis of Prosopis cineraria (L.) Druce in the State of Qatar. In: The Ghaf Tree. Prosopis cineraria in Qatar. Abdel Bari EM, Fahmy GM, AlThani NJ, Al-Thani RF and Abdel Dayem MS (eds). Environmental Studies Centre at Qatar university and National Council for Culture, Arts and Heritage; 2007.

[88] Whitford W., editor. Ecology of Desert Systems.Academic Press. Oxford; 2002.

[89] Compant S, Duffy B, Nowak J, Cle'ment C, Barka E. Use of Plant Growth-Promoting Bacteria for Biocontrol of Plant Diseases: Principles, Mechanisms of Action, and Future Prospects. Appli. Env. Microbiol. 2005; 71(9): 4951-4959. 
[90] Al-Thani R, Abd-El-Haleem D, Al- Shammri M. Isolation, Biochemical and Molecular Characterization of 2-chlorophenol Degrading Bacillus Isolates. Afric. J. Biotec. 2007; 6(23): 2675-2681.

[91] Al-Thani RF, Abd-El-Haleem DA, Al-Shammri M. Isolation and characterization of polyaromatic hydrocarbons-degrading bacteria from different Qatar soils. African J.Micro. Res.2009; 3(11): 761-766.

[92] Pieper DH, Reineke W. Engineering bacteria for bioremediation. Curr.Opin Biotec. 2000; 11(3): 262-270.

[93] Cohen MF, Yamasaki H, Mazzola M. Bioremediation of Soils by Plant-Microbe Systems Inter. J. Gree. 2004; 1(3): 301-312.

[94] Khan AG. Role of soil microbes in the rhizospheres of plants growing on trace metal contaminated soils in phytoremediation. J. Trace Elements in Med. Biol. 2005; 18 (4): 355-364.

[95] Zhuang X, Chen J, Shim H, Bai Z. New advances in plant growth-promoting rhizobacteria for bioremediation. Envi. Inter. 2007; 33(3): 406-413.

[96] Divya B, Kumar MD. Plant-Microbe Interaction with Enhanced Bioremediation. Res. J. Biotec. 2011; 6(4)72-79.

[97] Richer R. Conservation in Qatar: Impacts of Increasing Industrialization. Center for International and Regional Studies (CIRS), Georgetown University, School of Foreign Service in Qatar; 2008.

[98] Al-Ansi MA, Abdel-Bari EM, Yasseen BT, Al-Khayat JA. Coastal Restoration: Restoration of a coastal vegetation habitat at Ras Raffan industrial city. SARC, University of Qatar; 2004.

[99] Riegl B, Korrubel JL, Martin C. Mapping and monitoring of coral communities and their spatial patterns using a surface - based video method from a vessel. Bulletin of Marine Science 2001; 69 (2): $869-880$.

[100] Böer B, Al-Hajiri S. The coastal and sabkha flora of Qatar: An introduction. In: Barth HJ, Böer B (eds.) Sabkha ecosystems vol. 1: the Arabian peninsula and adjacent countries. Tasks for vegetation science 36. Kluwer Academic Publishers, The Netherlands; 2002. p 63-70.

[101] Muftah AMA. Diniflagellates of Qatar water. PhD thesis. University of Wales, UK; 1991.

[102] Moubasher AH., editor. Soil fungi in Qatar and other Arab countries. The Scientific and Applied Research Council, University of Qatar, Qatar; 1993.

[103] Al-Ansi MA. Fisherirs of the State of Qatar. PhD thesis. University of Aberdeen, UK; 1995.

[104] Rizk AM, El-Ghazaly GA., editors. Medicinal and poisonous plants of Qatar. The Scientific and Applied Research Centre, University of Qatar, Qatar; 1995.

[105] Jaman SK, Meakins R., editors. Biodiversity of Animals in Kuwait. Centre for Research and Studies on Kuwait, Kuwait; 1998.

[106] Al-Easa HS, Rizk AM, Abdel-Bari EM., editors. Chemical constituents and nutritive values of range plants in Qatar. The Scientific and Applied Research Centre, University of Qatar, Qatar; 2003. 
[107] Rizk AM, Al-Nowaihi AS., editors. The phytochemistry of the horticultural plants of Qatar. The Scientific and Applied Research Centre, University of Qatar, Doha, Qatar; 1989.

[108] Rizk AM, Al-Easa HS, Kornprobst JM., editors. The phytochemistry of the macro and blue-green algae of the Arabian Gulf. Faculty of Science, University of Qatar, Doha, Qatar; 1999.

[109] Abdel-Bari EM, Fahmy GM, Al-Thani NJ, Al-Thani RF, Abdel-Dayem MS., editors. The Ghaf tree, Prosopis cineraria in Qatar. Environmental Studies Centre, Qatar University, Qatar, ISBN 99921-58-88-3; 2007.

[110] Flowers TJ. Improving crop salt tolerance. J. of Exp. Bot. 2004; 55(396): 307-319.

[111] Riser-Roberts E., editor. Bioremediation of Petroleum Contaminated Sites. CRC Press, Boca Raton, FL; 1992.

[112] Khan FI, Husain T, Hejazi R. An overview and analysis of site remediation echnologies. Journal of Environmental management 2004; 71: 95-122.

[113] Frick CM, Farrell RE, Germida, JJ. Assessment of Phytoremediation as an InSituTechnique for Cleaning Oil-Contaminated Sites. Department of Soil Science University of Saskatchewan Saskatoon, SK Canada S7N 5A8, Submitted to: Petroleum Technology Alliance of Canada (PTAC) Calgary, A. 1999; http://www.clun.org/download/remed/phyassess.pdf.

[114] Vidali M. Bioremediation: An overview. Pur. Appl. Chem. 2001; 73 (7): 1163-1172.

[115] Ghosh M, Singh SP. A review on phytoremediation of heavy metals and utilization of ts byproducts. Applied Ecology and Environmental Research 2005; 3 (1): 1-18.

[116] Erakhrumen AA. Phytoremediation: an environmentally sound technology for pollution prevention, control and remediation in developing countries. Educational Research and Review 2007; 2 (7): 151-156.

[117] Jadia CD, Fulekar MH. Phytoremediation of heavy metals: Recent techniques. African ournal of Biotechnology 2009; 8 (6): 921-928.

[118] Baumann A. Das Verhalten von ZinksatzengegenPflanzen und im Boden. Landwirtsch.Vers.-Statn 1885; 31: 1-53.

[119] Hartman WJJr., editor. An evaluation of land treatment of municipal wastewater and physical siting of facility installations.Washington, DC, US Department of Army; 1975.

[120] Lasat MM. The use of plants for the removal of toxic metals from contaminated soil. Plant Physiology 1996; 118, 875-883.

[121] Van Epps A., editor. Phytoremediation of petroleum hydrocarbons. Environmental Careers Organization, U. S. Environmental Protection Agency Office of Solid Waste and Emergency Response Office of Superfund Remediation and Technology Innovation Washington, DC.; 2006.

[122] Carvalho KM, Martin DF. Removal of aqueous selenium by four aquatic plants. J. Aquat. Plant Manage. 2001, 39: 33 - 36.

[123] Hegazy AK, Abdel-Ghani NT, El-Chaghaby GA. Phytoremediation of industrial wastewater potentiality by Typha domingensis. Int. J. Environ. Sci. Tech. 2011; 8(3): 639 - 648.

[124] Nie M, Wang Y, Yu J, Xiao M, Jiang L, Yang J, Fang C, Chen J, Li B. Understanding Plant-Microbe Interactions for Phytoremediation of Petroleum-Polluted Soil. PLoS ONE 2011. 6(3): e17961. doi:10.1371/journal.pone.0017961. 
[125] Baker AJM, Brooks RR. Terrestrial higher plants which hyperaccumulate metallic elements - A eview of their distribution, ecology and phytochemistry. Biorecovery 1989; 1 (2): 81-126.

[126] Ebbs SD, Lasat MM, Brady DJ, Cornish J, Gordon R, Kochian IV. Phytoextraction of cadmium and zinc from a contaminated soil. J Environ Qual. 1997; 26(5): 1424-1430.

[127] Lone MI, He Z-L, Stoffella P, Yang X-E. Phytoremediation of heavy metal polluted soils and water: Progresses and perspectives. J Zhejiang Univ Sci B. 2008; 9 (3): 210-220.

[128] Czakó M, Feng X, He Y, Liang D, Márton L. Genetic modification of wetland grasses or phytoremediation. Z Naturforsch C. 2005; 60(3-4): 285-91.

[129] Hegedus R, Koseros T, Gal D, Pekar F, Birone Oncsik M, Lakatos G. Potential phytoremediation function of energy plants (Tamarix tetrandapall. and Salix viminalisl.) $\mathrm{n}$ effluent treatment of an intensive fish farming system using geothermal water. ActaUniversitatisSapientiae, Agriculture and Environment. 2009; 1: 31 - 37.

[130] Prasad MNV. Phyto-products from Prosopis juliflora (Velvet mesquite) applied in Phytoremediation. Frontiers in Trace Elements Research and Education, $10^{\text {th }}$ nternational Conference on the Biogeochemistry of Trace Elements, 13-18 July 2009, held in Chihuahua, Chih, Mexico, http://icobte2009.cimav.edu.mx.

http://icobte2009.cimav.edu.mx

[131] Shukla OP, Juwarkar AA, Singh SK, Khan S, Rai UN. Growth responses and metal accumulation capabilities of woody plants during the phytoremediation of tannery sludge. Waste Manag. 2011; 31(1):115-23.

[132] Njoku KL, Akinola MO, Oboh BO. Phytoremediation of crude oil contaminated soil: The effect of growth of Glycine max on the physico-chemistry and crude oil contents of soil. Nature and Science 2009; 7 (10): 79 - 87.

[133] Mackova M, Dowling DN, Macek T. Phytoremediation and rhizoremediation, Theoretical Background (Focus on Biotechnology), Series Editors: Hofman M, Anné J. Springer, The Netherlands; 2006.

[134] Paz-Alberto AM, Sigua GC, Baui BG, Prudente JA. Phytoextraction of LeadContaminated Soil Using Vetivergrass (Vetiveria zizanioides L.), Cogongrass (Imperata cylindrica L.) and Carabaograss (Paspalum conjugatum L.). Env Sci Pollut Res. 2007; 14 7): 498-504.

[135] Epstein E, Norlyn JD, Rush DW, Kingsbury RW, Kelley DB, Cunningham GA, Wrona AF. Saline culture of crops : A genetic approach. Science 1980; 210: 399- 404.

[136] Norlyn JD. Breeding salt - tolerant crop plants. In: Rains DW, Valentine RC, Hollaender A. (eds.) Genetic engineering of osmoregulation, impact on plant productivity for food, chemicals and energy. Plenum pub. New York; 1980. p 293 - 309.

[137] Winter SR, Musick JT, Porter KB. Evaluation of screening techniques for breeding drought - resistant winter wheat. Crop Sci. 1988; 28: 512 - 516.

[138] Yasseen BT, Al-Omary SS. An analysis of the effects of water stress on leaf growth and yield of three barley cultivars. Irrig. Sci. 1994;14:157 - 162.

[139] Yasseen BT, Al-Maamari BKS. Further evaluation of the resistance of Black barley to water stress: preliminary assessment for selecting drought resistant barley. J. Agron. and Crop Sci.1995; 174: 9-19. 
[140] Zhu J - K. Genetic analysis of plant salt tolerance using Arabidopsis. Plant Physiol. 2000; $124: 941-948$.

[141] Hawkesford MJ, Buchner P., editors. Molecular analysis of plant adaptation to the environment. Kluwer Academic Publishers, Dordrecht; 2001.

[142] Xiong L, Zhu J-K. Abiotic stress signal transduction in plants: Molecular and genetic perspectives. Physiol. Plant. 2001; 112: 152 - 166.

[143] Gopal J, Iwama K. In vitro screening of potato against water stress mediated through sorbitol and polyethylene glycol. Plant Cell Rep. 2007; 26: 693-700.

[144] Aazami MA, Torabi M, Jalili E. In vitro response of promising tomato genotypes for olerance to osmotic stress. African Journal of Biotechnology 2010; 9(26): 4014-4017.

[145] Saenger P., editor. Mangrove Ecology, Silverculture and Conservation. Kluwer Academic Publishers, Dordrecht; 2002.

[146] Orsini F, D’Urzo MP, Inan G, Serra S, Oh D-H, Mickelbart MV, Consiglio F, Li X, Jeong C, Yun D-J, Bohnert HJ, Bressan R A, Maggio A. A comparative study of salt tolerance parameters in 11 wild relatives of Arabidopsis thaliana. Journal of Experimental Botany 2010; 61(13): 3787-3798. doi:10.1093/jxb/erq188.

[147] Xiong L, Zhu J-K. Molecular and genetic aspects of plant responses to osmotic stress. Plant, Cell and Environment 2002; 25: 131-139.

[148] Yamaguchi T, Blumwald E. Developing salt-tolerant crop plants: challenges and opportunities. Trends in Plant Science 2005; 10 (12): 615-620.

[149] Arzani A. Improving salinity tolerance in crop plants: a biotechnological view. In Vitro Cellular and Developmental Biology-Plant 2008; 44 (5): 373-383.

[150] Ezawa S, Tada Y. Identification of salt tolerance genes from the mangrove plant Bruguiera gymnorhiza using Agrobacterium functional screening. Plant Science 2009; 176 2): 272-278.

[151] Flathman PE, Lanza GR. Phytoremediation: Current views on an emerging green echnology. J. Soil Contamination 1998; 7(4): 415-432.

[152] Kärenlampi S, Schat H, Vangronsveld J, Verkleij JAC, Lelie D. Genetic engineering in he improvement of plants for phytoremediation of metal polluted soils. Environ. Pollut. 2000; 107: 225-231.

[153] Ruiz ON, Hussein HS, Terry N, Daniell H. Phytoremediation of organomercurial compounds via chloroplast genetic engineering. Plant Physiol. 2003; 132: 1344-1352

[154] Fulekar MH, Singh A, Bhaduri AM. Genetic engineering strategies for enhancing phytoremediation of heavy metals. African Journal of Biotechnology 2009; 8 (4): 529-535

[155] Cunningham SD, Ow DW. Promises and prospects of phytoremediation. Plant Physiol. 1996; 110: 715-719.

[156] Van Aken B, Correa PA, Schnoor JL. Phytoremediation of Polychlorinated Biphenyls: New Trends and Promises. Environ Sci Technol. 2010; 44(8): 2767-2776. doi:10.1021/es902514d.

[157] Mudgal V, Madaan N, Mudgal A. Heavy metals in plants: phytoremediation: Plants used to remediate heavy metal pollution. Agriculture and Biology Journal of North America 2010; 1(1): 40-46. 